\title{
COARSE-GRAINED, DEEP-WATER SEDIMENTATION ALONG A BORDER FAULT MARGIN OF LAKE MALAWI, AFRICA: SEISMIC STRATIGRAPHIC ANALYSIS
}

\author{
MICHAEL J. SOREGHAN ${ }^{1}$, CHRISTOPHER A. SCHOLZ2 , AND JOHN T. WELLS ${ }^{3}$ \\ ${ }^{1}$ School of Geology and Geophysics, The University of Oklahoma, Norman, Oklahoma 73019, U.S.A. \\ ${ }^{2}$ Department of Earth Sciences, 219 Heroy Geology Laboratory, Syracuse University, Syracuse, New York 13244, U.S.A. \\ e-mail: cascholz@syr.edu \\ ${ }^{3}$ Institute of Marine Sciences, The University of North Carolina, Morehead City, North Carolina 28577, U.S.A.
}

\begin{abstract}
Aвstract: Lake Malawi, Africa, serves as an important modern analog for understanding depositional processes in an active rift setting. This paper explores the depositional processes and stacking patterns of coarse-grained facies across a large fan delta and associated sublacustrine fan system offshore of the South Rukuru River using singlechannel seismic data coupled with deep-water vibracores and gravity cores. A companion paper (Wells et al. 1999) discusses the details of the depositional processes of the system inferred from core data.

Using $2900 \mathrm{~km}$ of single-channel seismic data, eight genetic facies were defined based on seismic reflection character, external geometry, accompanying core data, and location within the modern geomorphic system. Five sand-dominated facies include: (1) mouth-of-canyon-fan facies; (2) progradational-fan-delta facies; (3) channel-fill facies; (4) canyon-fill facies; and (5) basin-plain-fill facies. These facies occur as surficial deposits in water depths of more than $600 \mathrm{~m}$, suggesting that coarse-grained sedimentation characterizes certain localities, in even the deepest parts of Lake Malawi.

Climatically driven lake-level changes influenced the internal character of these facies, their thickness, and to some extent their location within the South Rukuru study area. However, climate was generally subordinate to tectonism in controlling the temporal and spatial distribution of the facies. Tectonic controls can be categorized as: (1) orientation of the first-order border fault and intrabasinal faults; (2) syndepositional footwall uplift and rotation; and (3) temporal changes in the rate and location of maximum subsidence. These controls affect the location and stacking of the mouth-of-canyon fans, and the presence and orientation of sub-lacustrine canyons and the zone of maximum sediment accumulation, and depositional gradients.
\end{abstract}

\section{INTRODUCTION}

Lacustrine rift basins contain some of the most prolific hydrocarbon source rocks of any depositional setting. Hydrocarbon exploration efforts in ancient rift-lake basins have begun to target syn-rift reservoir facies, particularly in frontier basins such as West Africa, Brazil, and China (Ma et al. 1981; Bertani and Carozzi 1984; Zha 1984; Abrahao and Warme 1990; McHargue 1990; Bracken 1994; Harris et al. 1994; Magnavita and da Silva 1995). Exploration in these settings requires accurate prediction of reservoir facies, both in terms of size and scale of the reservoir, and the composition and internal character of the sediment constituting the reservoir. However, because rift-lake deposits typically exhibit abrupt vertical and lateral facies changes, caused by the active tectonic nature of these basins and climatically driven changes in lake level, accurate prediction of syn-rift reservoirs is difficult. Nevertheless, based on studies of the East African rift lakes, extensive coarse-grained deposits in direct contact with rocks containing up to $10 \%$ TOC are possible (Tiercelin et al. 1992; Scholz 1995a, 1995b; Soreghan and Cohen 1996), making the rewards of syn-rift reservoirs considerable.

In spite of the attractiveness of syn-rift reservoir facies for hydrocarbon exploration, few studies exist that combine sedimentologic and seismic data into stratigraphic models for deep-water, rift-lake sedimentation at a field scale. Although detailed models exist for deep-water sedimentation in ma- rine settings (e.g., Shanmugam and Moiola 1991; Weimer and Link 1991) it is unclear whether they are directly transferable to lacustrine settings because of the considerable differences in both temporal and volumetric scales of the system. Fluctuations of lake level occur on a much higher temporal frequency compared to eustatic sea-level fluctuations, which are postulated to drive facies stacking in marine settings (Shanmugam et al. 1985; Posamentier and Vail 1988). Also, high-frequency fluctuations in tectonic subsidence rates cannot be ruled out in an active rift setting, as they are along mature passive margins. Therefore, it is unclear whether the standard basin-floor fan model is appropriate in deep-water, rift-lake settings.

This paper presents preliminary results of an integrated study utilizing core and single-channel seismic data collected from a border-fault margin within Lake Malawi, Africa. The goals of this study are: (1) to characterize sand-dominated facies along an active border-fault margin of a rift lake, and (2) develop a predictive model based on these data to explain distribution of sand-dominated facies in terms of tectonic and climatic processes affecting rift-lake settings. This study focused on the part of Lake Malawi offshore of the South Rukuru River. Approximately $900 \mathrm{~km}$ of data were acquired in 1992 (Scholz 1995b) and an additional $2000 \mathrm{~km}$ were collected in 1995 to cover considerably more area and to better define the full range of depositional environments present. In addition, in 1995, a suite of deepwater cores were collected for the present study using an oceanic-scale vibracoring system. The combined seismic-sedimentologic data allows us to document the distribution and geometry of coarse-grained facies and the sedimentologic processes that formed them.

\section{BACKGROUND}

\section{Regional Geologic Setting}

Lake Malawi lies within the western arm of the East African Rift System and is the southernmost of the large East African Rift lakes (Fig. 1). Structurally the East African Rift System consists of a series of half grabens, 80-160 km long and 30-80 km wide, that link end to end down the rift axis (Rosendahl et al. 1986; Rosendahl 1987; Ebinger 1989a). In this geometry, the major basin-bounding fault segments alternately face west and east down the rift axis. The individual half grabens are linked by complex structural zones termed accommodation zones (transfer zones of Nelson et al. 1992) that accommodate strain and differential subsidence between two adjacent half grabens (Rosendahl et al. 1986; Ebinger 1989b; Morley et al. 1990; Nelson et al. 1992).

Lake Malawi consists of three main half-graben basins, although several smaller basins and sub-basins exist (Fig. 1; Ebinger et al. 1987; Specht and Rosendahl 1989). Multichannel seismic data indicate that up to 4 or $5 \mathrm{~km}$ of sediment have filled the depocenters of the individual half grabens (Specht and Rosendahl 1989). The footwall blocks of the basin-bounding faults rise $1.5 \mathrm{~km}$ above lake level, producing basement relief of up to 6.5 $\mathrm{km}$ in some locations. Multichannel seismic data indicate that the basinbounding faults are steeply dipping and planar, and fault surfaces control the position of the present lake shoreline (Specht and Rosendahl 1989). The hanging-wall block of each half graben generally exhibits a gentle gradient ramping away from the basin-bounding fault, although intense internal faulting, with fault traces parallel to the rift axis, is also prevalent. 


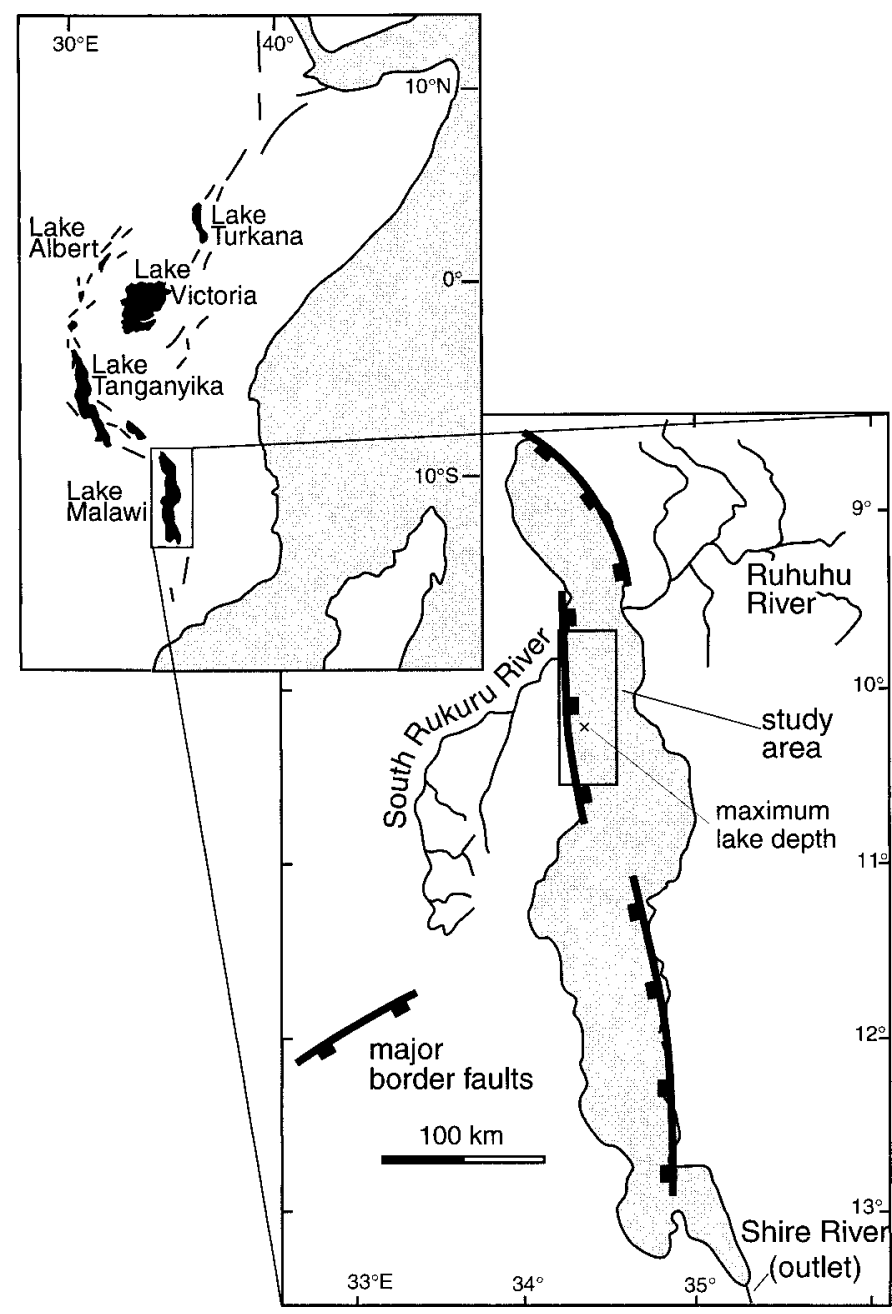

FIg. 1.-Location map of the southern end of the East African Rift System. Enlarged view illustrates generalized tectonic framework of Lake Malawi, which consists of three main border-fault segments producing three alternating half grabens.

The study site is centered offshore of the South Rukuru River, one of the seven large drainages to enter Lake Malawi (Fig. 1). It is the only large river to enter the lake across a major basin-bounding fault. The South Rukuru River may be an antecedent drainage system that flowed northeast prior to uplift of the border fault through which it now cuts (Crossley 1984). As footwall uplift progressed during rifting, the South Rukuru River downcut the rising rift-flank mountains. The present drainage area of the South Rukuru River is $11,900 \mathrm{~km}^{2}$, and the river drains through Karooage sedimentary rocks (mainly red beds) and Precambrian rocks (mainly metasediments) (Malawi Department of Surveys 1983). The South Rukuru River has built a relatively small modern fan delta along the margin of the lake, and the lake bottom slopes steeply away from the river mouth (Johnson et al. 1995).

\section{Hydrology and Climate}

Lake Malawi is $580 \mathrm{~km}$ long and up to $80 \mathrm{~km}$ wide and has a maximum water depth of about $700 \mathrm{~m}$. Rainfall within the Lake Malawi basin ranges from $800 \mathrm{~mm} / \mathrm{yr}$ in the southern part of the lake to over $2400 \mathrm{~mm} / \mathrm{yr}$ in the far north (Malawi Department of Surveys 1983). Most of the rain falls during the austral summer (December to March), when the winds are calm. The austral winter is mainly dry but experiences persistent southerly winds.

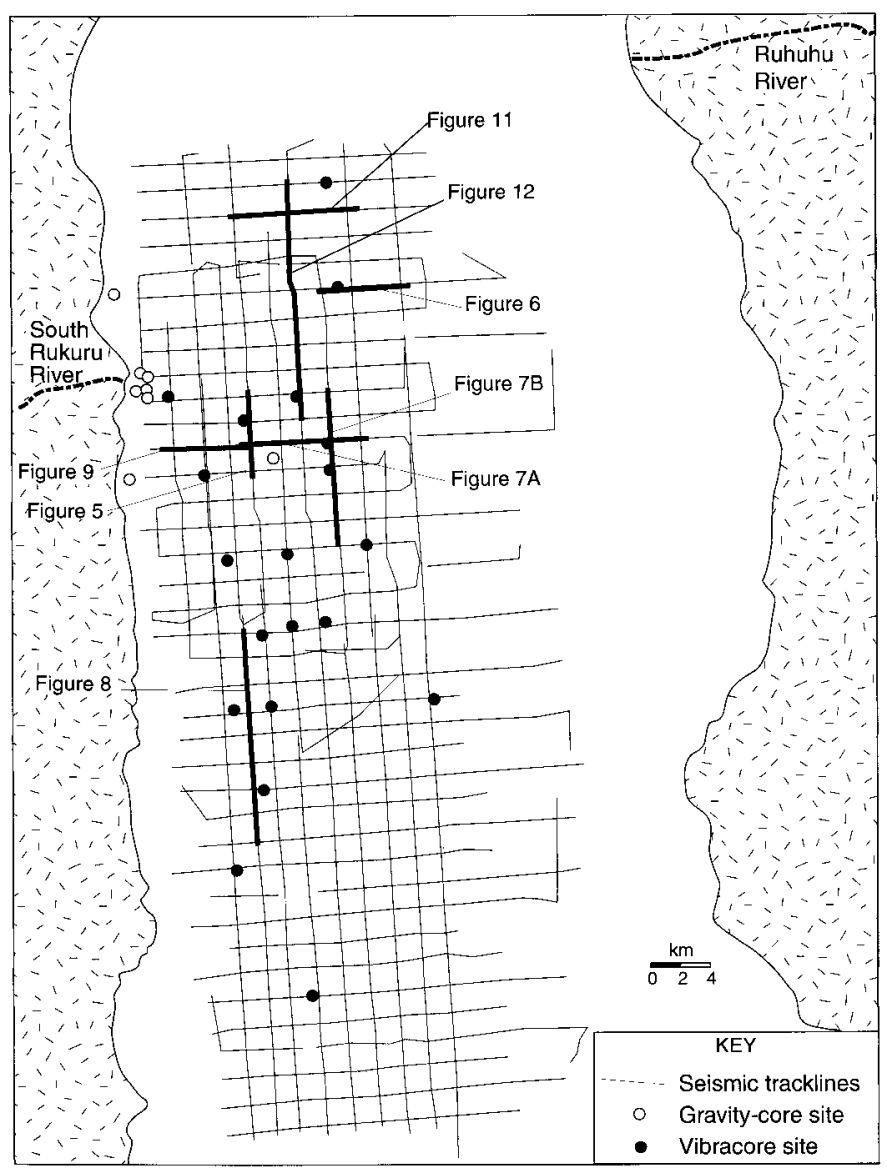

FIG. 2.-South Rukuru River study area with single-channel seismic trackline grids from 1992 and 1995 surveys as well as core locations. Bold lines indicate location of seismic profiles shown in subsequent Figures.

Lake Malawi is drained through the Shire River in the far south, although most water loss is by direct evaporation. The lake is thermally stratified, with mixing occurring only in the upper $250 \mathrm{~m}$ of the water column; below 250 m water depth the lake waters are permanently anoxic (Halfman 1993). The lake waters are fresh, and exhibit low alkalinity.

\section{METHODS}

More than $2000 \mathrm{~km}$ of single-channel digital seismic reflection data were acquired offshore of the South Rukuru River in 1995 (Fig. 2). These data overlap a smaller grid of single-channel seismic data collected offshore of the South Rukuru River in 1992 (Scholz 1995b). Grid spacing is approximately $2 \mathrm{~km}$ over most of the study area, allowing for reasonably detailed mapping of seismic facies geometries and for constraining structural components of the study site. Navigation during acquisition was controlled by a GPS system in autonomous mode. The seismic source was a 12 inch $^{3}$ airgun detonated at $2000 \mathrm{psi}$. The data bandwidth was $\sim 50-500 \mathrm{~Hz}$, producing a vertical resolution of $\sim 1-2 \mathrm{~m}$. The seismic reflection signals were received using an ITI, 10-phone solid towed array and recorded using an Elics-Delph 2 seismic acquisition system. The sample rate was $0.5 \mathrm{~ms}$, and data were acquired with a nominal trace spacing of $10 \mathrm{~m}$. Data processing included a three-trace horizontal stack, band-pass filtering (80-500 $\mathrm{Hz}$ ), application of a $100 \mathrm{~ms}$ AGC (automatic gain control) window, and trace balancing.

In addition to the seismic data, 20 deep-water cores were collected using 


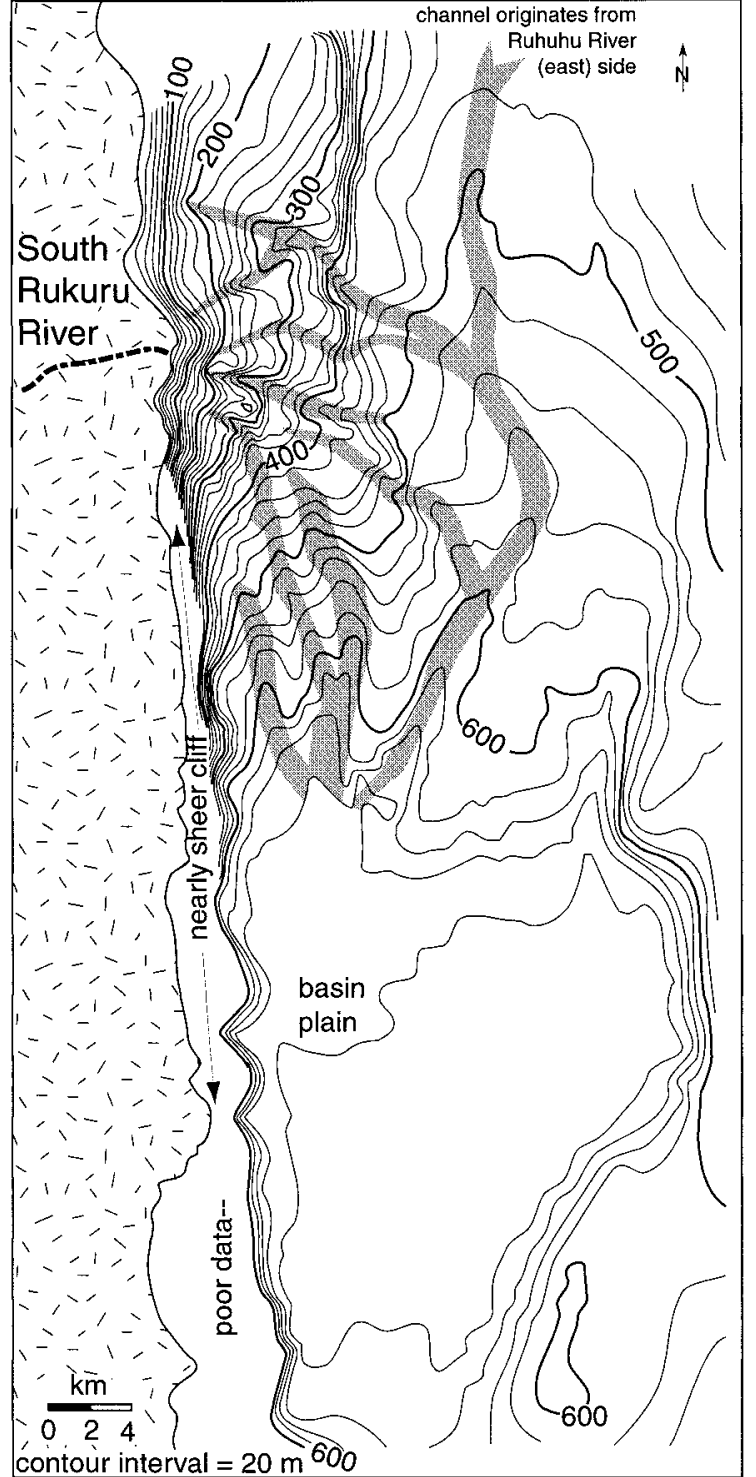

FIg. 3.-Bathymetric map of study area constructed from single-channel seismic data. Contour interval is $20 \mathrm{~m}$, which translates to $27 \mathrm{~ms}$ of two-way travel time (TWTT) on seismic data. Stippled areas represent subaqueous channels and canyons.

an electric vibracoring system (Fig. 2). These cores, which were able to sample coarse-grained deposits in water depths between $265 \mathrm{~m}$ and $677 \mathrm{~m}$, supplemented short gravity cores collected in the same vicinity in 1992. Details of the coring system and the subsequent core analysis are given in the companion paper (Wells et al. 1999). These cores were collected to "ground-truth" the acoustic character of the uppermost reflections and to infer sedimentary processes of the active depositional system.

\section{RESULTS}

\section{Structure of Border-Fault Margin from Reflection Seismic Data}

The major basin-bounding fault along the study site is coincident with the modern shoreline and extends for approximately $130 \mathrm{~km}$ along shore (Figs. 1, 3, 4). The present uplifted footwall block rises $1500 \mathrm{~m}$ above present lake level, and pre-rift basement on the hanging-wall block lies up to 2 seconds two-way travel time (TWTT) below present lake level (Specht

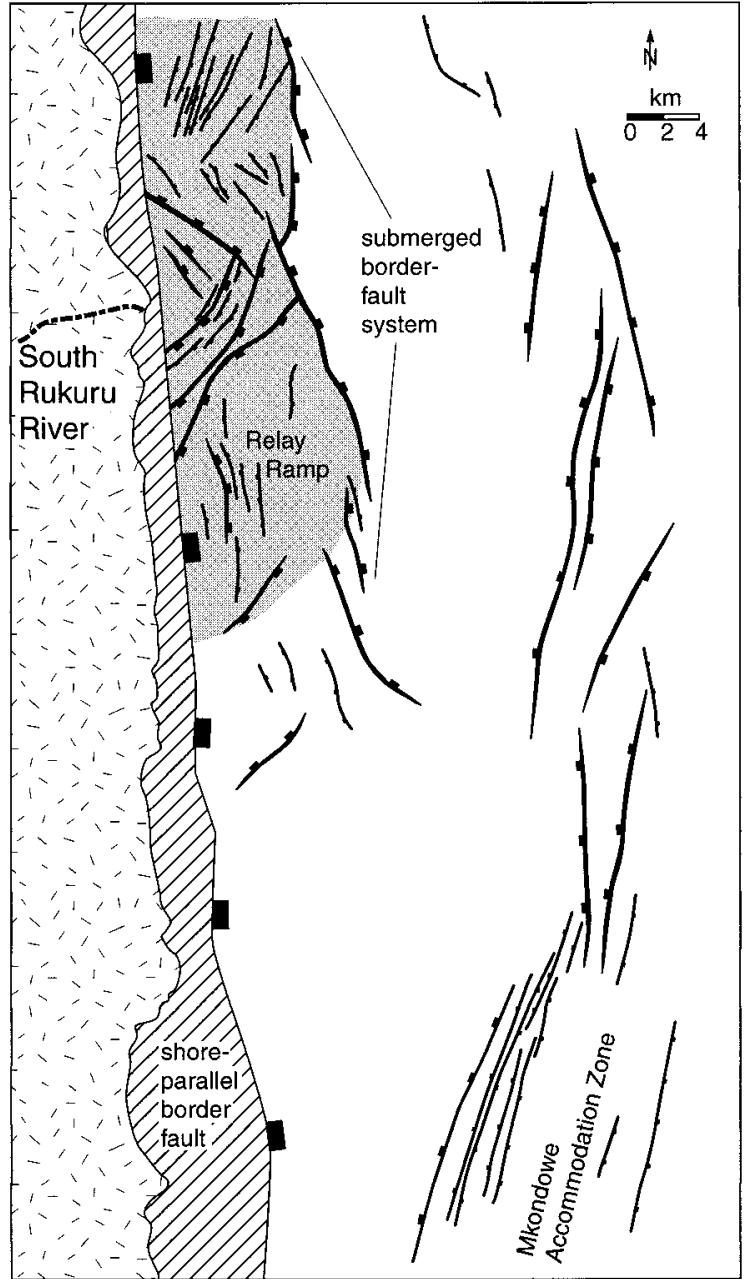

FIG. 4.-Fault map of study area constructed from single-channel seismic data. Hachures represent downdropped sides of fault. Faults were mapped on a mid-level horizon that was carried across study area. Labeled features are referred to in text.

and Rosendahl 1989). Therefore, cumulative displacement along this basinbounding fault is inferred to be $3.5 \mathrm{~km}$.

A submerged escarpment approximately $10 \mathrm{~km}$ offshore (Fig. 3) is formed by a series of west-dipping, en echelon, down-to-the-east faults extending for at least $40 \mathrm{~km}$ parallel to shore (Fig. 4). At the north end of the study site, displacement of an intermediate-depth reflector across this fault system is approximately $0.25 \mathrm{~s}$ TWTT, and this displacement decreases toward the south. At the north end of the study site, the submerged fault system produces a bathymetric escarpment with relief of $140 \mathrm{~m}$ (Fig. 3), but at the southern terminus of this offshore fault system the fault trace is buried by a thin veneer of sediment. Along the north and central parts of the fault system the bathymetric escarpment is incised by at least three major canyons (Fig. 3). Eastward of this submerged fault system the basin is much less deformed, deepens to over $500 \mathrm{~m}$ water depth, and slopes gently to the south.

The region between the border fault along the shore and the subaqueous border fault is a relay ramp containing a series of mostly down-to-thesoutheast, northeast-striking faults spaced less than $1 \mathrm{~km}$ apart (Fig. 4). Displacements along these faults are generally minor (less than $40 \mathrm{~ms}$ TWTT) across a mid-depth reflector. A conjugate set of faults that trend northwest are also present along this relay ramp. The relay ramp dips to the south-southeast, although internal faulting creates a complex bathy- 
TABLE 1.-Facies Characteristics.

\begin{tabular}{|c|c|c|c|c|c|}
\hline Facies & Seismic Reflection Character & External Seismic Geometry & Scale* & Sediment Texture & Stratification \\
\hline Canyon-Fill Facies & $\begin{array}{l}\text {-High- to moderate-amplitude, cha- } \\
\text { otic to discontinuous reflections } \\
\text {-Internal terminations common }\end{array}$ & $\begin{array}{l}\text {-Concave-up basal surface-erosional trunca- } \\
\text { tions } \\
\bullet \text { Onlapping basal terminations } \\
\text { •Irregular upper surface }\end{array}$ & $\begin{array}{l}-2 \mathrm{~km} \text { wide and up to } 15 \\
\mathrm{~km} \text { long } \\
-120 \mathrm{~ms} \text { thick }\end{array}$ & $\begin{array}{l}\text { sand/gravel }=77-53 \% \\
\text { silt }=14-26 \\
\text { clay }=9-21\end{array}$ & $\begin{array}{l}\text { Stacked, fining-up, mixed sand and grav- } \\
\text { el beds ( } 0.5-1.25 \mathrm{~m} \text { thick) intercalated } \\
\text { with wavy- to parallel-laminated silt. } \\
\text { Mud clasts common. Cores from upper } \\
\text { canyons contain thicker intervals of } \\
\text { mud. }\end{array}$ \\
\hline Channel-Fill Facies & $\begin{array}{l}\text {-High- to moderate-amplitude, semi- } \\
\text { continuous to discontinuous reflec- } \\
\text { tions } \\
\text {-Occasional internal termination }\end{array}$ & $\begin{array}{l}\text {-Low-relief, concave-up basal surface } \\
\bullet \text { Onlapping basal terminations } \\
\bullet \text { Convex-up to planar upper surface }\end{array}$ & $\begin{array}{l}\text { - } 1 \mathrm{~km} \text { wide and up to } 30 \\
\mathrm{~km} \text { long } \\
\text { 40 ms thick }\end{array}$ & $\begin{array}{l}\text { sand } / \text { gravel }=62 \% \\
\text { silt }=13 \\
\text { clay }=25\end{array}$ & $\begin{array}{l}\text { Stacked, graded turbidite units ( } 0.5 \text { to } 1.0 \\
\text { m thick) intercalated with thick inter- } \\
\text { vals of laminated to homogeneous } \\
\text { mud. Deformed laminae and sand } \\
\text { flames common. Mud clasts absent. }\end{array}$ \\
\hline $\begin{array}{l}\text { Mouth-of-Canyon- } \\
\text { Fan Facies }\end{array}$ & $\begin{array}{l}\text { - Low- to moderate-amplitude, trans- } \\
\text { parent to discontinuous reflections. } \\
\text {-Occasional hummocky reflections } \\
\text { and internal termination }\end{array}$ & $\begin{array}{l}\text {-Planar to slightly concave-up basal surface } \\
\text {-Downlapping to shingled basal terminations } \\
\text {-Upper surface is convex-up }\end{array}$ & $\begin{array}{l}\bullet 0 \mathrm{~km}^{2} \text { in area } \\
\bullet 100 \mathrm{~ms} \text { thick }\end{array}$ & $\begin{array}{l}\text { sand } / \text { gravel }=85 \% \\
\text { silt }=7 \\
\text { clay }=8\end{array}$ & $\begin{array}{l}\text { Amalgamated coarsening- and fining-up } \\
\text { beds. Very little intercalated mud on } \\
\text { fan crest. Grading less distinct than in } \\
\text { canyon and channel fill. Rip-up clasts } \\
\text { absent. Maximum clast size } 1-3 \mathrm{~cm} \text {. }\end{array}$ \\
\hline $\begin{array}{l}\text { Basin-Plain Fill Fa- } \\
\text { cies }\end{array}$ & $\begin{array}{l}\text {-High- to moderate-amplitude, semi- } \\
\text { continuous to discontinuous reflec- } \\
\text { tions. } \\
\text { - Parallel to divergent internal reflec- } \\
\text { tion }\end{array}$ & $\begin{array}{l}\text {-Planar to slightly concave-up basal surface } \\
\text {-Onlapping basal terminations } \\
\text {-Upper surface is flat to concave-up }\end{array}$ & $\begin{array}{l}\bullet 160 \mathrm{~km}^{2} \text { in area } \\
\bullet 120 \mathrm{~ms} \text { thick }\end{array}$ & $\begin{array}{l}\text { sand/gravel }=16 \% \\
\text { silt }=27 \\
\text { clay }=57\end{array}$ & $\begin{array}{l}\text { Thick intervals of stiff massive mud ( }>1 \\
\mathrm{~m} \text { thick) intercalated with both fining- } \\
\text { up sandy and coarser, massive beds. } \\
\text { The massive beds have a mud matrix } \\
\text { and common mud clasts. }\end{array}$ \\
\hline $\begin{array}{l}\text { Progradational Fan- } \\
\text { Delta Facies }\end{array}$ & $\begin{array}{l}\text {-Low-amplitude, discontinuous re- } \\
\text { flections } \\
\text { •Well-developed clinoform packages }\end{array}$ & $\begin{array}{l}\text {-Planar basal surface } \\
\text {-Downlapping basal terminations } \\
\text {-Upper surface concave-down-toplap to par- } \\
\text { allel terminations }\end{array}$ & $\begin{array}{l}\bullet 40 \mathrm{~km}^{2} \text { in area } \\
\bullet 50 \mathrm{~ms} \text { thick }\end{array}$ & no data & no data \\
\hline Levee Facies & $\begin{array}{l}\text {-High-amplitude, semicontinuous re- } \\
\text { flections } \\
\text { •Parallel internal reflections. }\end{array}$ & $\begin{array}{l}\text {-Parallel basal surface and basal reflections. } \\
\text {-Upper surface concave-down: uppermost re- } \\
\text { flections parallel to surface but underlain by } \\
\text { truncated reflections. }\end{array}$ & $\begin{array}{l}\bullet 10 \mathrm{~km} \text { long and } 1 \mathrm{~km} \\
\text { wide } \\
\text {-25 ms thick }\end{array}$ & $\begin{array}{l}\text { sand } / \text { gravel }=17 \% \\
\text { silt }=26 \\
\text { clay }=57\end{array}$ & $\begin{array}{l}\text { Thick intervals of laminated and massive } \\
\text { mud intercalated with thin }(<5 \mathrm{~cm}) \\
\text { fining-up sandy beds. Inclined bed- } \\
\text { ding, cross-bedding, microfaulting, and } \\
\text { sand flames are common within sandy } \\
\text { intervals. }\end{array}$ \\
\hline $\begin{array}{l}\text { Hemipelagic Drape } \\
\text { Facies }\end{array}$ & $\begin{array}{l}\text {-High-amplitude, continuous reflec- } \\
\text { tions. } \\
\text {-Parallel to slightly divergent inter- } \\
\text { nal reflections. }\end{array}$ & $\begin{array}{l}\text {-Basal surface follows underlying topography } \\
\text {-Parallel basal reflections above this surface. } \\
\text {-Upper surface is planar }\end{array}$ & $\begin{array}{l}\bullet 300 \mathrm{~km}^{2} \text { in area } \\
\text { - } 30 \mathrm{~ms} \text { thick }\end{array}$ & $\begin{array}{l}\text { sand/gravel }=12 \% \\
\text { silt }=26 \\
\text { clay }=62\end{array}$ & $\begin{array}{l}\text { Mostly thinly laminated to homogeneous } \\
\text { mud. Thin "starved" silty laminae } \\
\text { present. }\end{array}$ \\
\hline $\begin{array}{l}\text { Mixed Turbidite } \\
\text { Hemipelagic Facies }\end{array}$ & $\begin{array}{l}\text {-High- to moderate-amplitude, semi- } \\
\text { continuous to discontinuous reflec- } \\
\text { tions. } \\
\text {-Parallel to divergent internal reflec- } \\
\text { tions. }\end{array}$ & $\begin{array}{l}\text {-Planar basal surface } \\
\text {-Parallel to shingled basal reflections } \\
\text {-Upper surface planar }\end{array}$ & $\begin{array}{l}\bullet 200 \mathrm{~km}^{2} \text { in area. } \\
\text { - } 60 \mathrm{~ms} \text { thick }\end{array}$ & $\begin{array}{l}\text { sand } / \text { gravel }=26 \% \\
\text { silt }=29 \\
\text { clay }=45\end{array}$ & $\begin{array}{l}\text { Mostly thinly laminated to homogeneous } \\
\text { mud intercalated with both fining-up } \\
\text { and massive sandy beds (up to } 50 \mathrm{~cm} \\
\text { thick). Massive beds moderately well } \\
\text { sorted, but no apparent structures. }\end{array}$ \\
\hline
\end{tabular}

* Values given are maximum values for area, width, length, and thickness. Thickness measured in milliseconds (ms) two-way travel time.

metric morphology characterized by a series of incised channels that coalesce at the base of the south-dipping ramp (Fig. 3).

The eastern margin of the study site is mainly characterized by a series of down-to-the-west intrabasinal normal faults that confine the deep basin on the east (Fig. 4). Displacements along these faults vary significantly but are generally less than $200 \mathrm{~ms}$ TWTT across the mid-depth reflector described previously. This fault system trends from the northern edge of the study area mostly due south for approximately $50 \mathrm{~km}$, where it merges with the northeast-southwest-trending Mkondowe accommodation zone, previously identified by Specht and Rosendahl (1989).

The modern depocenter is located at the southern end of the study area and is bordered by the shore-coincident border fault on the west, the relay ramp on the north, and the Mkondowe accommodation zone on the south and east (Fig. 3). This appears to have been the major depocenter throughout much of the recent rift history. Thickness trends of lower seismic stratigraphic intervals, however, indicate that the zone of maximum sediment accumulation has progressively shifted southward through time from a prior location east of the submerged border fault to its present location at the south end of the relay ramp.

\section{Seismic Facies}

Seismic facies were initially defined within the uppermost depositional interval in regions where sediment core was available. The core data allowed us to link seismic character to both sedimentologic character and inferred depositional processes. These data are discussed in detail in a related article (Wells et al. 1999) and are discussed only briefly here. The seismic facies were defined on the basis of internal seismic characteristics (amplitude, reflection continuity), external geometry, and termination types along bounding surfaces (Table 1). Because of the availability of core data and the fact that the seismic facies were defined within a modern depositional system, we have used a genetic facies classification scheme.

The following are brief descriptions of each facies, starting with the sand-dominated facies. Each section includes a description of the seismic characteristics and accompanying core data followed by interpretations of those characteristics.

\section{Sand-Dominated Facies}

Canyon-Fill Facies.-This facies consists of high-amplitude but chaotic to hummocky and discontinuous reflections (Table 1, Fig. 5). The basal contact is erosional, and basal reflections commonly show abrupt truncation against this surface. The numerous erosional truncations (Fig. 5) suggest that the canyons are permanent and have experienced several phases of cutting and filling. Cores collected from the upper parts of these canyons consist of stacked fining-up sequences (Table 1, Fig. 5). The basal parts of these fining-up sequences commonly contain angular gravel and mud clasts (Fig. 5), the latter consistent with cut-and-fill processes. The canyon-fill facies is imaged in the single-channel seismic data by chaotic to discontinuous reflections (Fig. 5). Downgradient on the relay ramp, the canyons broaden and become shallower, and core data indicate that the fill facies consist of thinner $(<1 \mathrm{~m})$ but more abundant, stacked gravity-flow deposits exhibiting well-developed fining-upward sequences (Wells et al. 1999). 


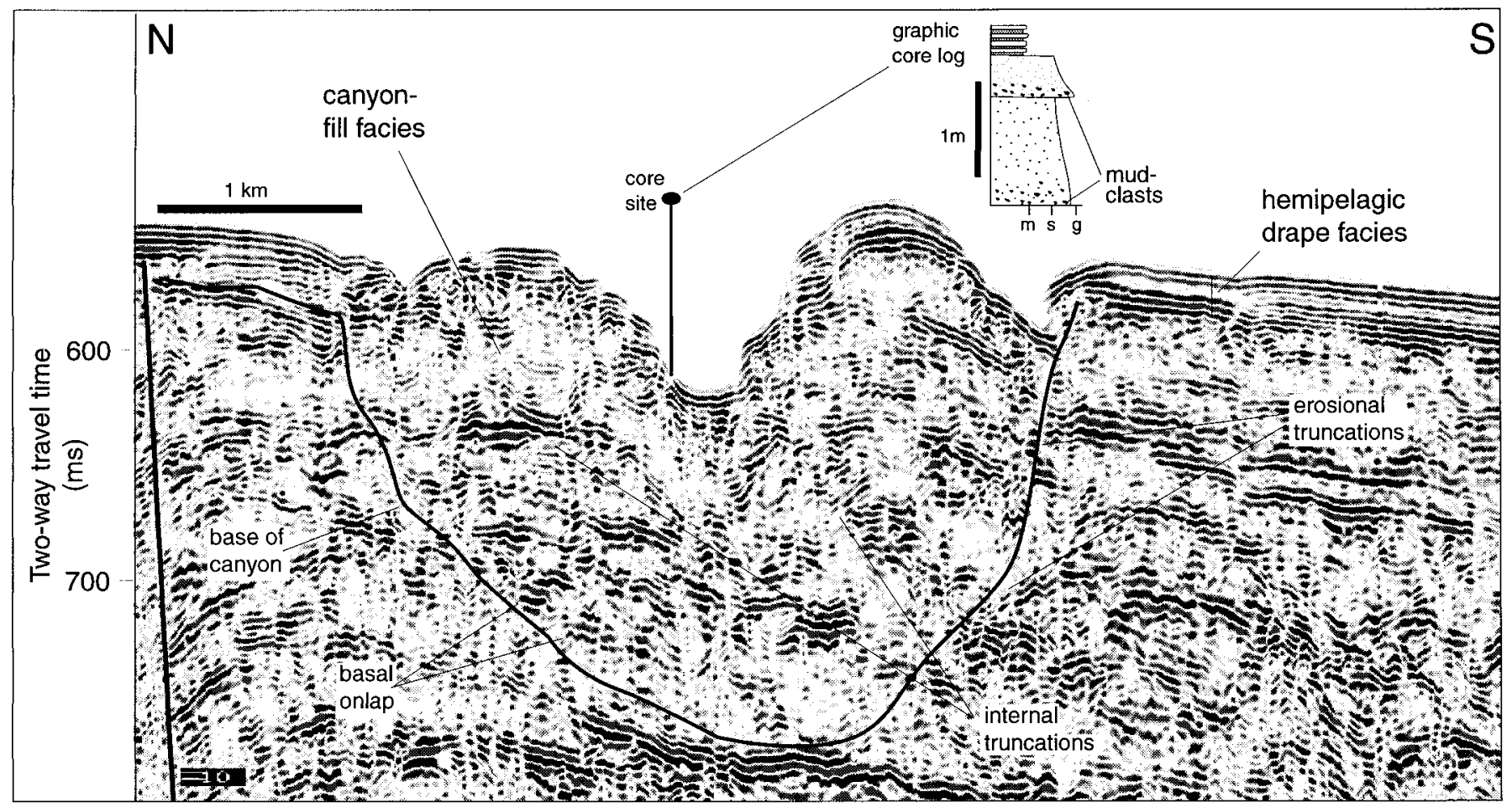

FIg. 5.-Single-channel seismic profile and simplified graphic core log (for all core logs, see Wells et al. 1999 for detailed descriptions) illustrating canyon-fill facies. Profile oriented parallel to shoreline; see Figure 2 for location of line. Note internal reflection truncations suggesting multiple cut-and-fill episodes within canyon.

Channel-Fill Facies.-This facies consists of variable-amplitude, semicontinuous to discontinuous reflections (Table 1). The basal contact is slightly concave-up but irregular, and the upper contact is usually uneven to hummocky or concave-up (Fig. 6). This facies is distinguished from the canyon-fill facies by the location of the channels off the submerged footwall blocks and by the observation that the channels are broader, shallower, and more meandering than the canyons. The facies also contains less gravel than the canyon-fill facies (Table 1). Cored intervals of this facies contain thin gravity-flow deposits $(<0.5 \mathrm{~m}$ thick $)$ that exhibit a well-developed fining-up sequence (Table 1, Fig. 6) and exhibit distorted bedding and numerous "sand flames" (Wells et al. 1999). The meandering nature of the channel, the acoustic character of the channel-fill facies, and the common association of levees (Fig. 6) suggest that the channels are more constructional than erosional in form.

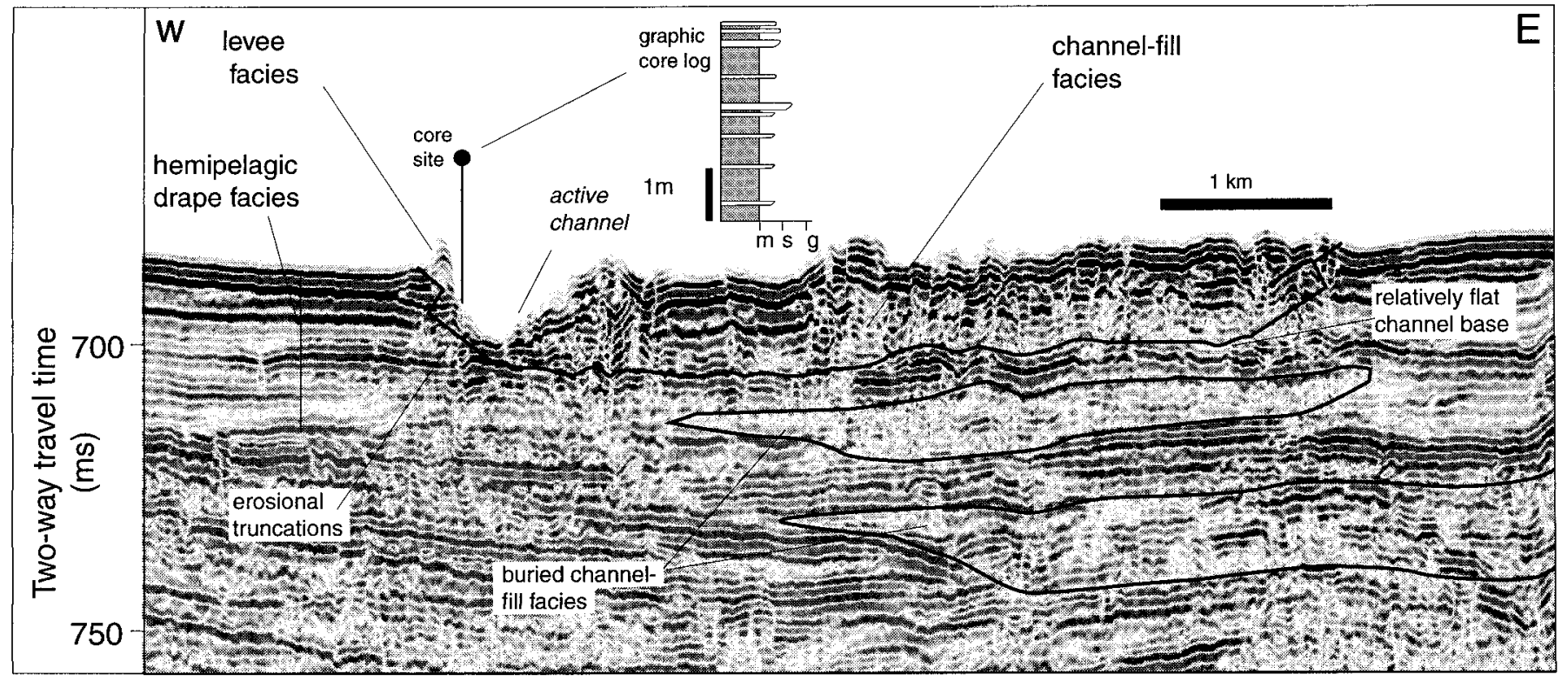

FIG. 6.-Single-channel seismic profile and simplified graphic core log illustrating channel-fill facies. Profile oriented perpendicular to shoreline; see Figure 2 for location of line. Note that channel-fill deposits are present exclusively to the east of the active channel. 

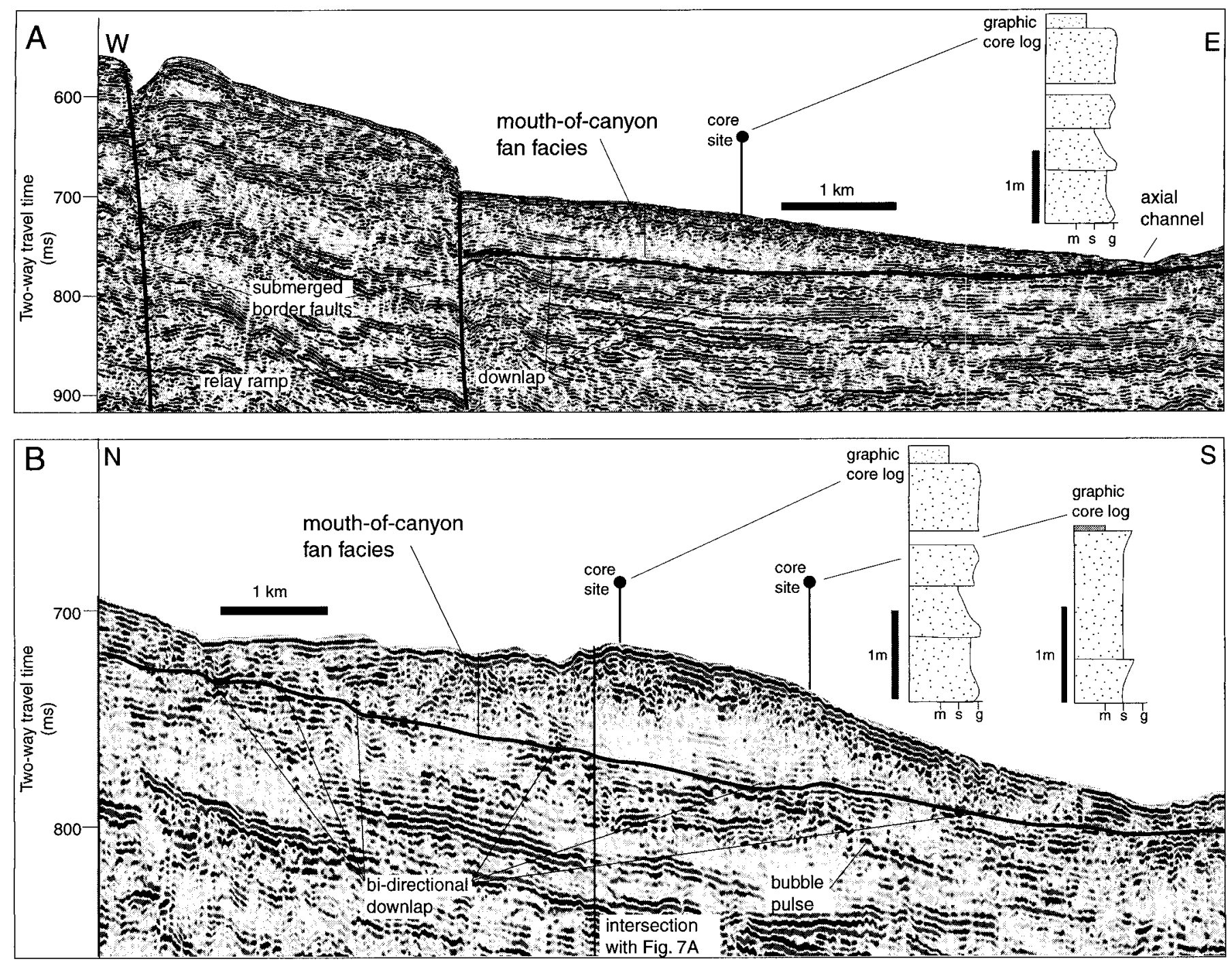

FIG. 7.-A) Single-channel seismic profile and simplified graphic core log illustrating mouth-of-canyon-fan facies. Profile oriented perpendicular to shoreline; see Figure 2 for location of line. Note downlapping reflectors at base of package and active axial channel located at distal edge. B) Single-channel seismic profile illustrating same mouth-of-canyon fan as shown in Figure 7A, but oriented parallel to shoreline (strike view). Note bidirectional downlapping reflectors at base of package and mounded external geometry. Core sites were projected onto this line.

Mouth-of-Canyon-Fan Facies.-Within this facies, the internal character of reflections varies significantly from bottom to top (Table 1, Fig. 7A). The lower part of the facies is characterized by low-amplitude, discontinuous reflections that laterally become transparent. The upper part of the facies is characterized by more moderate-amplitude, discontinuous to hummocky reflections. The external geometry is typically wedge shaped down dip (Fig. 7A) and lenticular in strike view (Fig. 7B). The basal surface is characterized by parallel reflections and subordinate downlapping terminations in dip view (Fig. 7A), and exhibits parallel to bidirectional downlapping reflections in strike view (Fig. 7B). Core from this facies consist of a series of thick, massive mass-flow deposits that exhibit only minimal grading (Table 1, Fig. 7A). This facies represents the highest netsand-to-gross thickness of any of the facies cored (Wells et al. 1999).

Basin-Plain-Fill Facies.-This facies consists of high-amplitude to moderate-amplitude, discontinuous reflections (Table 1) that exhibit a filltype external geometry characterized by basal onlapping reflections and some internal terminations (Fig. 8). The sediment consists of a mixture of debris flows, turbidites, and hemipelagic mud (Table 1; Wells et al. 1999).
The thickness and frequency of coarse-grained event beds within this facies decrease to the south (Fig. 8). This facies reflects aggradation at the base of a broad slope of coarse-grained gravity-driven sedimentation intermixed with hemipelagic sedimentation in the zone of maximum sediment accumulation.

Progradational-Fan-Delta Facies.-The progradational-fan-delta facies is not expressed at the surface, but only deep within the single-channel seismic data; however, it may be analogous to the modern fan delta constructed off the South Rukuru River. The seismic character of this facies is typified by low-amplitude, low-continuity reflections that display well developed downlap (clinoform) terminations along the lower surface, whereas the upper surface is commonly characterized by toplap terminations (Table 1, Fig. 9). Core data from a similar facies in the southern part of Lake Malawi (Martin 1997) suggest that these clinoform reflections consist mostly of coarse-grained sand and gravel. Scholz (1995b) originally named this same unit a lowstand delta. By analogy to the modern fan delta, we similarly interpret this facies as mass-flow and bed-load deposits on the subaerial to subaqueous part of a fan delta or coarse-grained delta. 


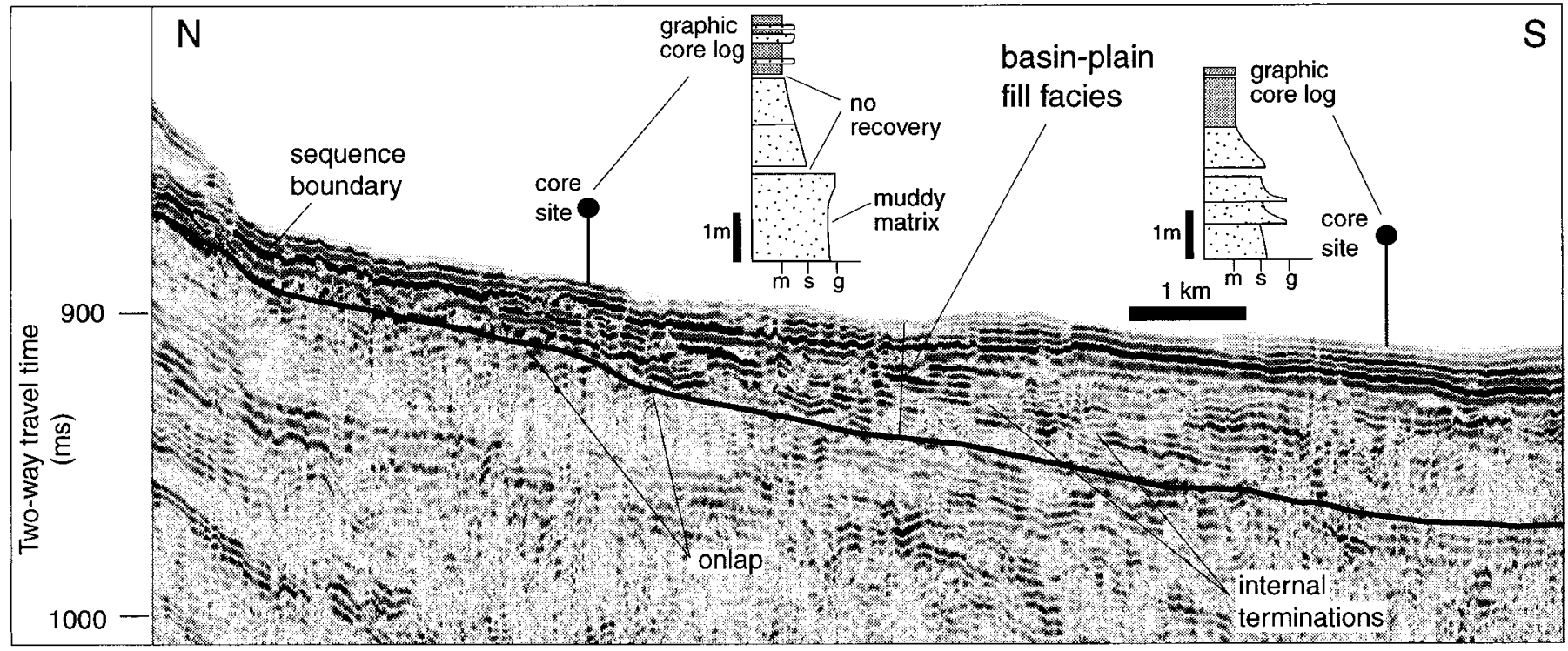

FIG. 8.-Single-channel seismic profile and simplified graphic core log illustrating basin-plain-fill facies. Profile oriented parallel to shoreline; see Figure 2 for location of line. Note onlapping reflectors at base of package and divergent external geometry.

\section{Mud-Dominated Facies}

Levee Facies.-This facies consists of moderate-amplitude to high-amplitude, continuous reflections that exhibit a broad mounded external geometry adjacent to axial sub-lacustrine channels (Table 1, Fig. 6). The levee facies consists of mixed hemipelagic mud and thin, fining-up sandy horizons (Table 1; Wells et. al. 1999). The mud is commonly massive, although intervals of very finely laminated mud are also present (Wells et al. 1999). The levee facies presently is restricted to a position along the sub-lacustrine channels where their gradient decreases abruptly. This facies is not well imaged at depth by the seismic data, and its paucity may be a function of either: (1) reworking of the levee sediments during lateral channel migration, or (2) loss of resolution in the seismic character between the levee facies and the laterally equivalent channel-fill facies.

Hemipelagic-Drape Facies.-This facies consists of variable-amplitude, very continuous reflections (Table 1) exhibiting a sheet-like external geometry (Fig. 6). This facies consists of both very finely laminated to massive mud with very thin sand to silt horizons (Table 1; Wells et al. 1999). The facies reflects suspension deposition that onlaps or drapes original bathymetry and is very common over broad regions of the lake floor away from active gravity-flow deposition.

Mixed Turbidite/Hemipelagic Facies.-This facies consists of moderate-amplitude, discontinuous reflections (Table 1). Internally, the reflections commonly exhibit a shingled, westward-dipping character. The direction of the downlapping reflections suggests that the sediment is derived from the eastern margin of the lake, most likely the Ruhuhu River (Fig. 1). This facies is similar to the basin-plain-fill facies in both seismic character and interpreted depositional processes. The main difference between the two facies is the external geometry; the mixed turbidite/hemipelagic facies is sheet-like and generally thinner. The fine-grained nature of the sand and the low net sand to total thickness (Wells et al. 1999) indicates infrequent, waning, gravity-flow deposition across the broad, unchanneled lake floor.

\section{DISCUSSION}

\section{Distribution of Facies}

We were able to break most of the seismically imaged strata into ten depositional intervals (sequences) using standard seismic stratigraphic tech- niques. It is beyond the scope of this paper to discuss each interval in depth. The following discussion focuses on the spatial distribution of facies within the uppermost two depositional intervals and on the stacking pattern of the mouth-of-canyon-fan facies.

The distribution of the seismically defined facies within the modern environment is depicted in Figure 10. The most prominent of the sand-dominated facies is the mouth-of-canyon-fan facies located in the center of the study area adjacent to the submerged border fault (in approximately 540 $\mathrm{m}$ water depth). This facies is at least $40 \mathrm{~ms}$ TWTT thick over an area of $30 \mathrm{~km}^{2}$ with a maximum thickness of $85 \mathrm{~ms}$ TWTT. The core data suggest that the flanks of this fan are presently being draped by hemipelagic mud (Fig. 7B). The basin-plain-fill facies occupies the main depocenter at the break in slope along the south edge of the relay ramp (Fig. 10). This facies extends over a region of approximately $180 \mathrm{~km}^{2}$ and reaches a maximum thickness of $120 \mathrm{~ms}$ TWTT.

A series of prominent canyons and related canyon-fill facies occur within the upper depositional interval and can be observed on several shore-parallel seismic lines. A long-lived canyon, $1 \mathrm{~km}$ wide, 8-10 km long, 40-60 $\mathrm{m}$ deep, and partially infilled with the canyon-fill facies, feeds the prominent mouth-of-canyon fan. Along the relay ramp, canyon-fill facies occur within a series of coalescing canyons oriented north-south and cover a combined area $4 \mathrm{~km}$ wide and $14 \mathrm{~km}$ long (Fig. 10). A long, slightly sinuous axial channel and associated channel-fill facies runs parallel to the main border fault east of the submerged border-fault system (Fig. 10). This channel originates from the distal edge of the Ruhuhu fan delta, located on the eastern side of the lake and northeast of the study site. This axial channel is over $40 \mathrm{~km}$ long and up to $1.5 \mathrm{~km}$ wide. The active channel typically contains only minor amounts of fill facies and exhibits well-developed levee facies, particularly toward the southern end of the channel, where the channel coalesces with other channels derived from the relay ramp. The consistent occurrence of channel-fill facies on the eastern margin of the active channel and hemipelagic drape facies on the western margin of the channel suggests that this channel is actively migrating from east to west, incising westward into the hemipelagic drape facies (Fig. 6).

Within the immediately underlying depositional interval, the position of the sand-dominated facies shifted in location relative to the overlying, uppermost depositional interval. A prominent mouth-of-canyon fan is offset to the north of the location of the overlying mouth-of-canyon-fan facies 


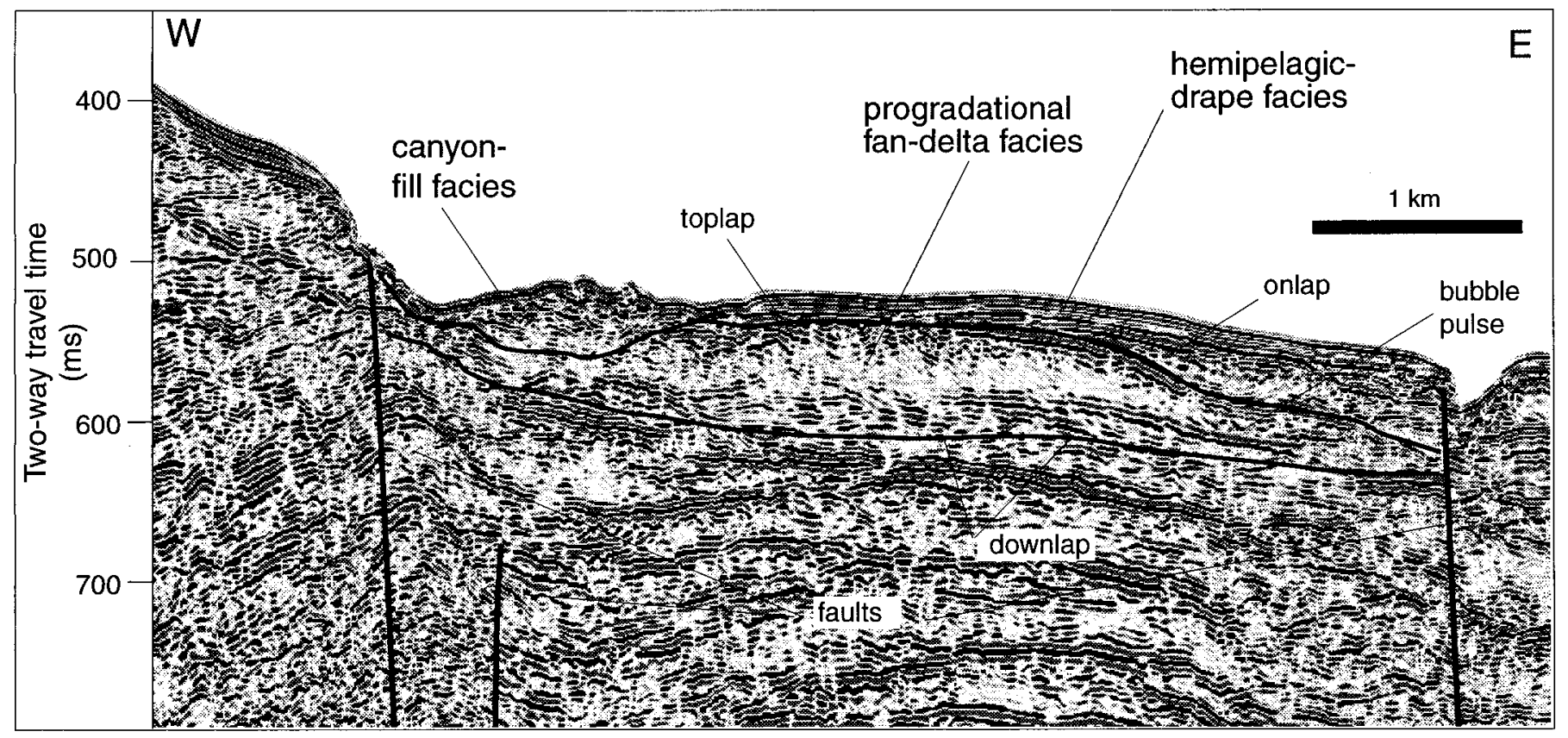

FIG. 9.- Single-channel seismic profile illustrating progradational-fan-delta facies. Profile oriented perpendicular to shoreline; see Figure 2 for location of line. Note well developed prograding clinoform reflectors. This facies is overlain by onlapping and draping hemipelagic-drape facies and is cut on its back (western edge) by a canyon that was subsequently filled with canyon-fill facies.

(Fig. 10). This lobe is $40 \mathrm{~ms}$ TWTT thick over approximately $30 \mathrm{~km}^{2}$, and attains a maximum thickness of $55 \mathrm{~ms}$ TWTT. A broad canyon, $3 \mathrm{~km}$ wide and 6-8 km long, located north of the modern canyon, fed the mouth-ofcanyon fan (Fig. 10). An axial channel (now buried) was present eastward of the submerged border fault and mouth-of-canyon-fan facies (Fig. 6), but mapping of the channel is complicated by subsequent channel migration of the modern axial channel. The basin-plain-fill facies within this interval is located in approximately the same location as in the overlying depositional interval, suggesting that the location of maximum sedimentation, the location of the relay ramp, and the break in slope at the base of this ramp were in approximately the same location for the most recent past. The basin-plain-fill facies during this interval covers an area of approximately $150 \mathrm{~km}^{2}$ and is up to $130 \mathrm{~ms}$ TWTT thick. The one facies observed in this interval not present in the uppermost depositional interval is the progradational-fan-delta facies, which occupies an area of at least $60 \mathrm{~km}^{2}$ on the relay ramp (Fig. 10). This package, with well developed clinoforms, is interpreted as the subaerial to shallow subaqueous part of a fan delta that prograded obliquely across the relay ramp to the edge of the submerged border fault.

Many of the same spatial patterns of facies distribution observed in the upper two sequences are also observed within the underlying intervals. For each of the underlying sequences, only one mouth-of-canyon fan is present adjacent to the submerged border system. These fans range from 10 to 40 $\mathrm{km}^{2}$ in area and are up to $120 \mathrm{~ms}$ TWTT thick. On dip lines these lobes appear to be stacked (Fig. 11), but in three dimensions, the stacking pattern is more complex. In strike view, the lobes form an en echelon, or shingled pattern (Fig. 12). The position of these lobes and their lateral distribution appear to be controlled by three long-lived canyons incised into the submerged border-fault footwall block (Fig. 3). The stacked, shingled pattern of the lobes indicates that the canyons were generally active at different times, and that the locations of successive lobes emanating from the same canyon were influenced by remnant bathymetric relief. The broad axial zone of channels and channel-fill facies appears to have existed during most of these depositional intervals, but it may have been more or less areally extensive. Identification of the progradational-fan-delta facies is generally restricted to the uppermost few intervals, mainly because of erosional reworking of the shallower, relay ramp over time. Finally, the basin-plain fan facies is also identified within most of the depositional intervals. The position of maximum sediment accumulation, as evidenced by a successive shift in the depocenter of the basin-plain-fill facies, appears to migrate to the south during successively younger depositional intervals.

\section{Tectonic Controls on Facies Distribution}

Both the active tectonic volatility and climate-induced fluctuations in lake level contribute to the complex facies stacking pattern observed in the sand-dominated facies. Figure 13 summarizes the main tectonic variables inferred to affect the position and development of sand-dominated facies within the South Rukuru study area. These tectonic controls are defined as: (1) fault orientation; (2) intrabasinal footwall uplift and rotation, and (3) temporal changes in fault-driven tectonic subsidence. Each of these controls affects the distribution, orientation, and/or ultimate thickness of the sanddominated facies.

The position of both the major basin-bounding and intrabasinal faults control the location and orientation of the sub-lacustrine canyons and hence the location of the mouth-of-canyon fans (location A, Fig. 13). The control of the fault orientation on maintaining the location of fan or fan-delta deposits has been documented in many similar extensional settings where sediment was derived directly from the footwall block of major basinbounding faults (Blair and Bilodeau 1988; Gawthorpe and Colella 1990; Tiercelin et al. 1992; Dart et al. 1994; Magnavita and da Silva 1995). In the South Rukuru study site, the mouth-of-canyon fans consistently develop on the hanging-wall block directly adjacent to the submerged border-fault system (Fig. 11). However, through time successive lobe development migrated laterally along the fault scarp as only one canyon was active during each depositional interval.

Footwall uplift and block rotation along the submerged border faults, and the smaller synthetic faults on the relay ramp (location B, Fig. 13), coupled with fluctuations in lake level (discussed below) controls which canyon is active at any one time. Flexural uplift along the footwall block 


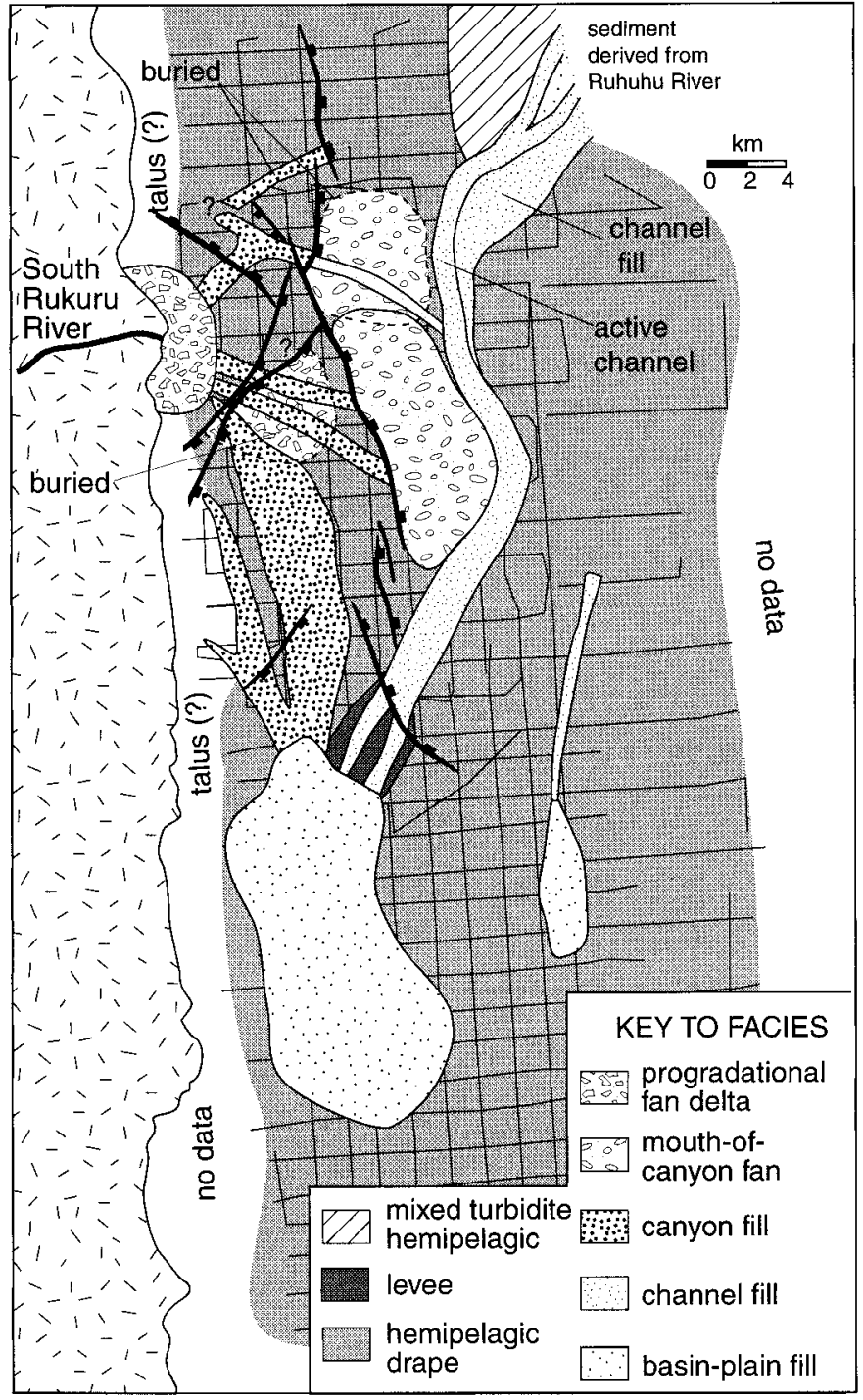

FIG. 10.-Distribution of seismically defined facies across the South Rukuru study site. Some of submerged normal faults that influence facies distributions are also depicted. Note that in three cases buried facies, which represent older periods of sedimentation, are depicted on the map and are discussed in the text.

of normal faults is predicted by models for extensional faults (King et al. 1988; Kusznir and Egan 1990; Weissel and Karner 1989). Similarly, we infer that the three canyons identified offshore of the South Rukuru River have been maintained through continued uplift of the footwall block along the shore-parallel border fault. The footwall block of the submerged border faults is characterized by a series of steeply westward-dipping and folded layers that exhibit internal folding and faulting (Scholz et al. 1993, their figure 3). These layers are truncated by a regional erosional surface (Scholz 1995b) that is in turn overlain by only a thin veneer of sediment, suggesting deformation and tilting of the footwall block has continued until very recent times. Canyon cutting in response to flexural uplift along the footwall block ensures that these incised canyons become long-lived features. Although active sediment transport alternated among the canyons cut into the submerged border fault over time, each canyon is permanent with little potential for migration during repeated changes in lake level.

Finally, changes in the rate of subsidence and collapse of the relay ramp control the distribution of the basin-plain-fill facies as well as the position of the axial channel (location C, Fig. 13). The basin-plain-fill facies oc- cupies the locus of most active subsidence. Therefore, the temporal shift in the maximum sediment thickness of the basin-plain-fill facies observed in the seismic data reflects a temporal shift in maximum tectonic subsidence. If the zone of maximum subsidence corresponds with the zone of maximum fault offset (Barnett et al. 1987; Walsh and Watterson 1989), then the region of most active displacement appears to have shifted from north to south over time. Temporal changes in the rate of subsidence also appear to control the position of the major axial channel system. The active axial channel appears to have migrated from east to west during the most recent depositional episode, as evidenced by axial-channel-fill deposits consistently located to the east of the active channel (Fig. 6). This westward shift in the position of the axial channel is toward the active border fault and the region of high rate of subsidence. A similar response of axial fluvial systems to the differential subsidence of a half graben is common in fluvialdominated rift systems (e.g., Rio Grande Rift; Mack and Seager 1990) and may also be a common feature of lacustrine- or marine-dominated rifts.

\section{Lake-Level Fluctuations Controlling Facies Distribution}

Lake-level fluctuations driven by climatic variations in precipitationevaporation balance are ubiquitous in tropical lakes in general, and have been documented for large lakes such as Malawi and Tanganyika over a variety of temporal scales (e.g., Livingstone 1965; Butzer et al. 1972; Haberyan and Hecky 1987; Scholz and Rosendahl 1988; Owen et al. 1990; Scholz and Finney 1994). Scholz and Rosendahl (1988) and Scholz (1995a, 1995b) have discussed the seismic evidence for large-magnitude fluctuations in lake level in Lake Malawi, such as erosional unconformities, downlapping reflections, and clinoform packages associated with lowstand deposition. These same features are observed in the South Rukuru seismic dataset and attest to signals of climatically driven fluctuations in lake level in the sedimentary record.

Climatically driven fluctuations in lake level, coupled with the tectonic effects discussed above, control the location and thickness of the mouthof-canyon-fan facies, the progradational-fan-delta facies, the axial-channel facies, and the basin-plain-fill facies. Figure 14 outlines the sequence of facies development during a rise and subsequent fall in lake level. The model shown in Figure 14 is generalized from the data analyzed in this study and assumes that both tectonic subsidence and sediment supply are relatively high.

During periods of low lake level (Fig. 14A), sediment is delivered to the relay ramp through the incised canyon in the main border-fault footwall. Sediment is derived directly from the footwall block and travels perpendicular to the rift axis (along the plane of Figure 14), building a fan delta that progrades across the relay ramp. The canyons generally experience sediment bypass, as evidenced by the sharp erosional boundaries in these canyons. Sediment is focused onto the mouth-of-canyon fans, which, because of the steep slopes and high rates of tectonic subsidence, aggrade rather than prograde (Gawthorpe et al. 1994). Sedimentation rates on these fans are probably highest during low lake level as the prior highstand deposits are reworked and transported directly to the mouth-of-canyon fans and fan delta through the incised canyons. Because sediment is actively aggrading on the mouth-of-canyon fans, sedimentation rates at the zone of maximum subsidence (basin-plain-fill facies) are probably minimal. During this time sediment may also be delivered to the deeper parts of the basin from the hanging-wall (east) side of the basin (Fig. 14A). The fan delta of the Ruhuhu River, which lies opposite the South Rukuru River (Fig. 1), exhibits a broad turbidite apron at its distal edges (Scholz 1995a, 1995b). At periods of low lake level, this apron may prograde outward into the basin center.

A subsequent rise in lake level submerges the sub-lacustrine canyons and relay ramp (Fig. 14B). Climatically driven rises in lake level are commonly rapid, particularly in tropical lake systems. Owen et al. (1990) calculated that a rise in lake level of $100 \mathrm{~m}$ could be accomplished in a few 

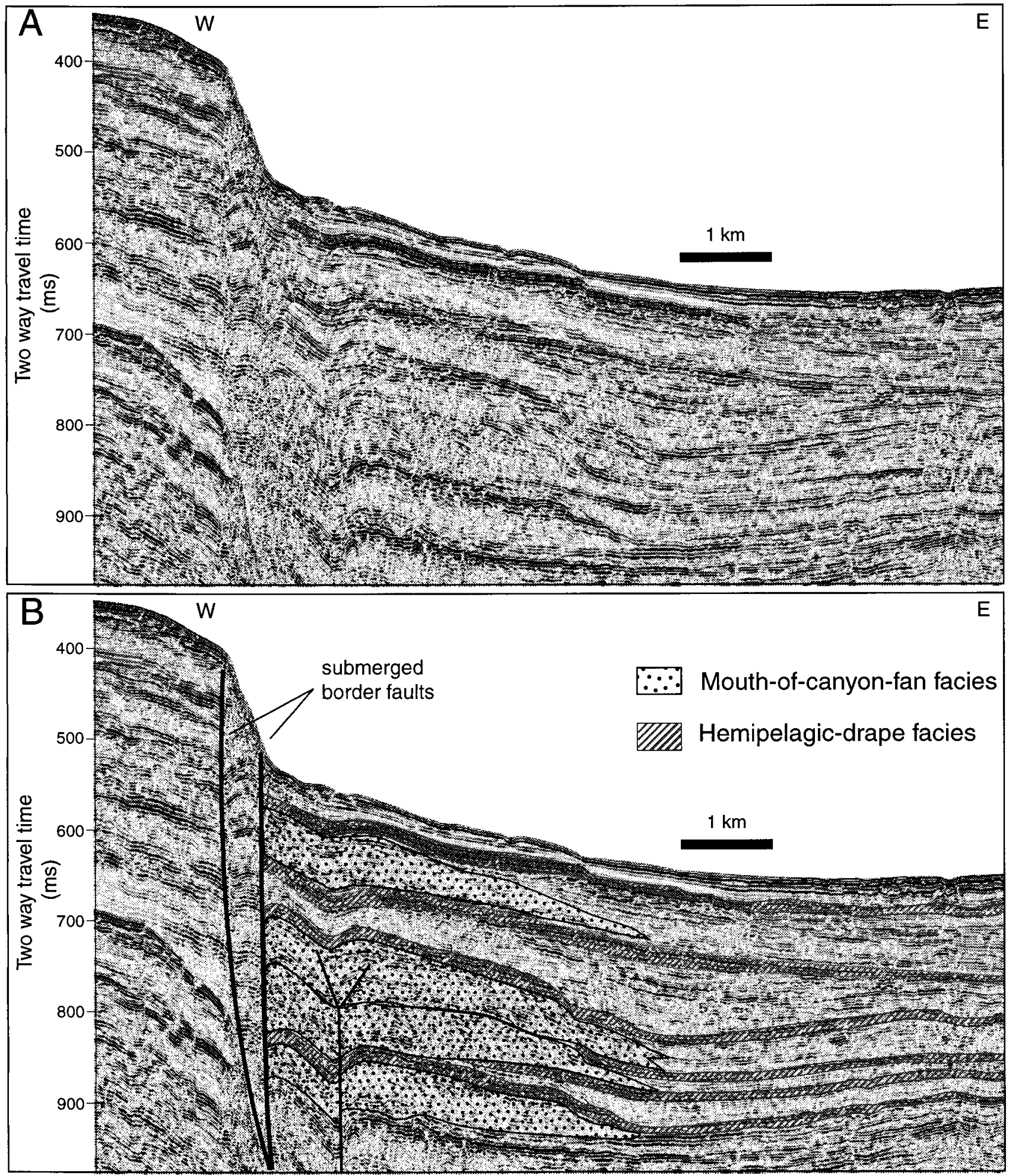

FIG. 11.-A) Uninterpreted and B) interpreted dip-oriented single-channel seismic profile illustrating a series of stacked mouth-of-canyon fans draped by the hemipelagic drape facies. In one case the mouth-of-canyon fans are amalgamated, with the intervening hemipelagic drape facies missing. In another case a mouth-of-canyon fan has not developed, replaced by the basin-plain-fill facies between two hemipelagic drape intervals. 

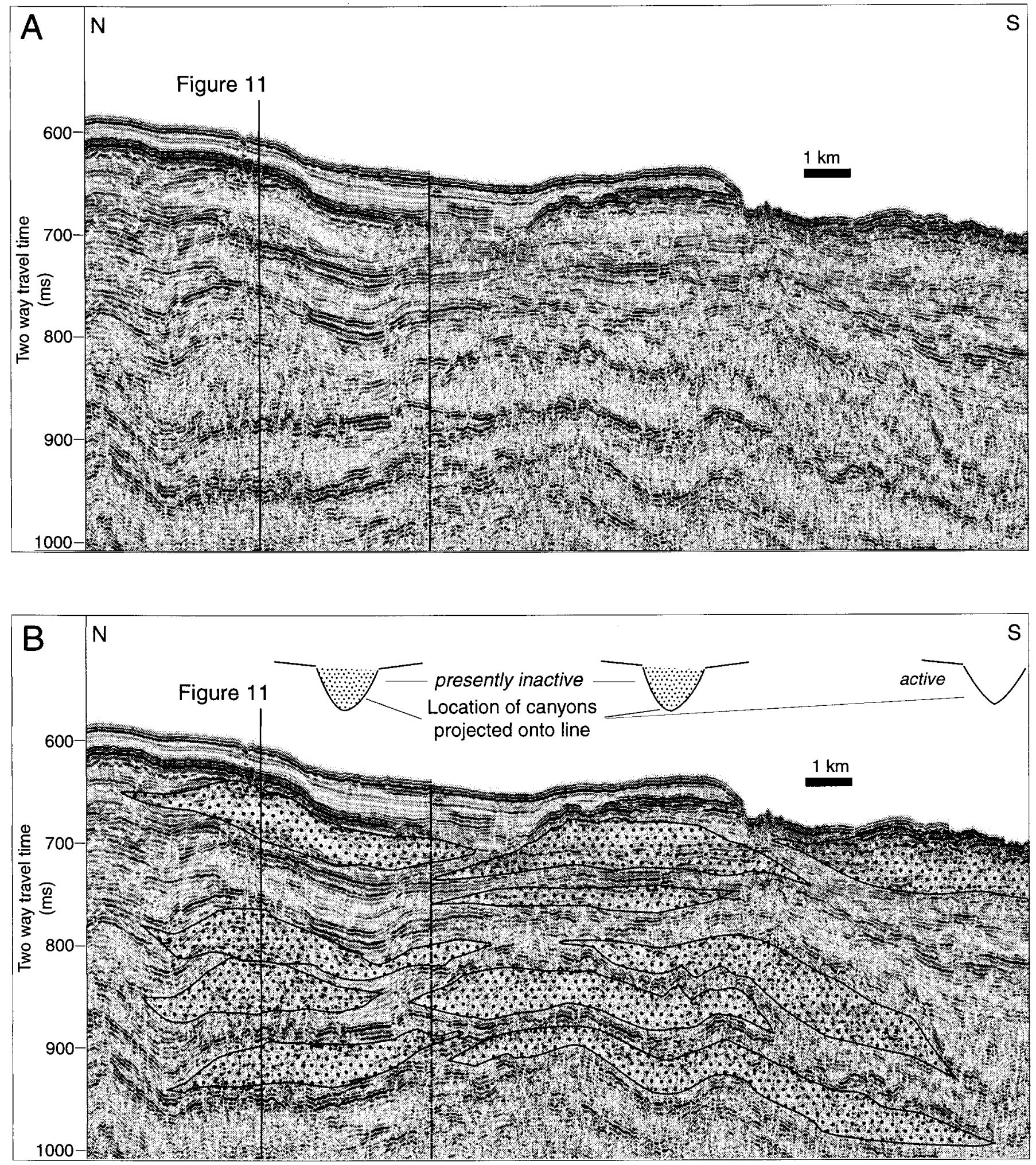

FIG. 12.-A) Uninterpreted and B) interpreted strike-oriented single-channel seismic profile illustrating the shingled nature of the mouth-of-canyon fans located offshore of the submerged border fault. Vertical line represents intersection with dip profile pictured in Figure 11. Locations of canyons cut into footwall block of submerged border faults are also projected onto plane of line. Note that fans appear to overlap, suggesting that one fan was active during any one depositional interval. See text for further discussion. 


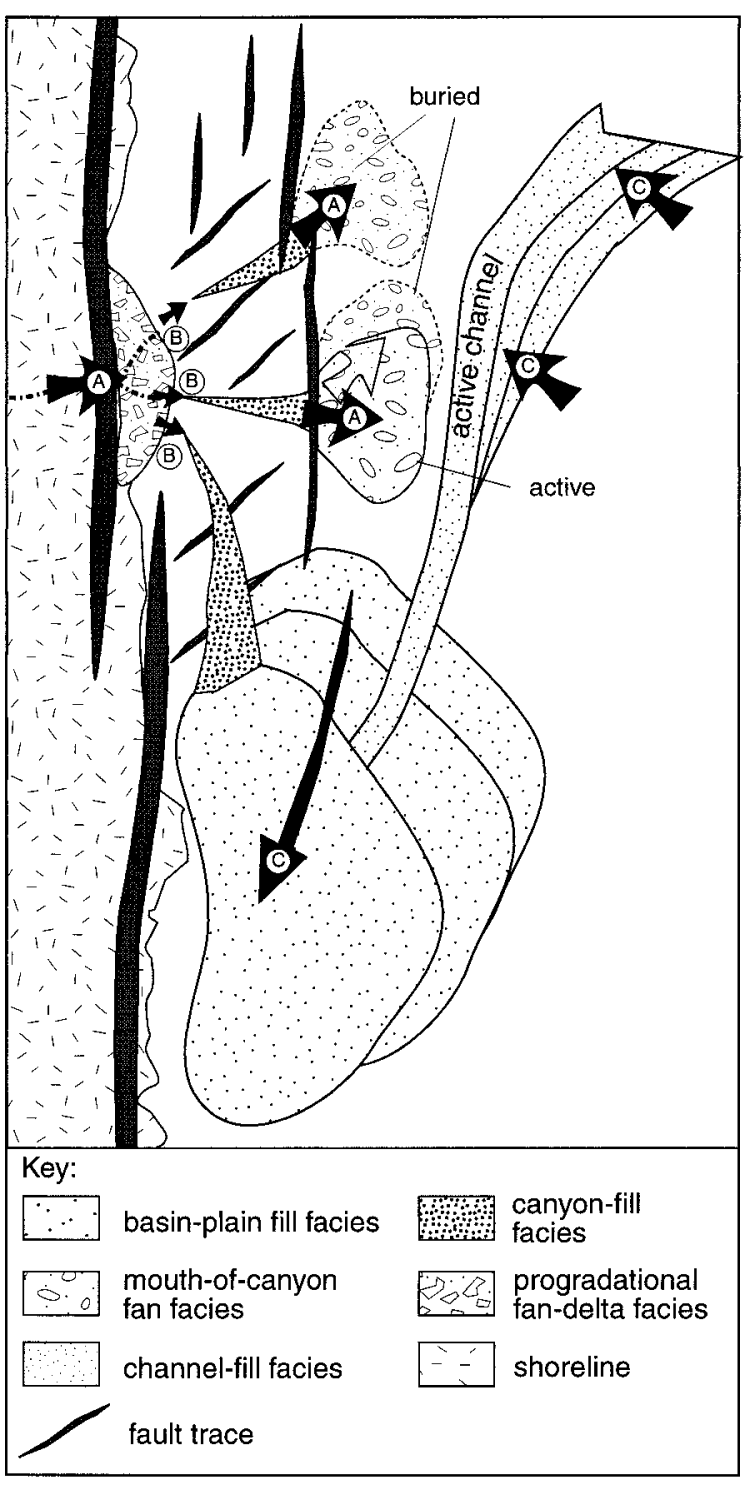

FIG. 13.-Summary of tectonic controls influencing sedimentation along a borderfault margin that contains a submerged, secondary border fault. Labeled arrows are referred to in text.

hundred years with a $20 \%$ increase in precipitation. A rapid rise in lake level would alter sediment dispersal paths, pond sediment farther up on the footwall block, and consequently reduce coarse-grained sedimentation to the mouth-of-canyon fans. Some coarse sediment may be delivered to the apex of the fan through the sub-lacustrine canyon, both from river discharge and from subaqueous slumping. However, we infer from the seismic data that most of the depositional area is blanketed by a thin veneer of hemipelagic mud, forming the continuous, relatively high-amplitude reflections.

During the phase of high lake level, a fan delta begins to develop at the new shoreline, on or adjacent to the main basin-bounding fault (Fig. 14C). As the relay ramp is drowned, the overall downslope gradient is down the axis of the relay ramp, parallel to the shoreline (in an out of the plane of Figure 14C). Therefore, sediment dispersal is primarily to the south (in the case of the South Rukuru River) and the sediment accumulates at the base of the relay ramp rather than the base of the submerged border-fault system. Figure 14C also depicts sedimentation derived from an axial source (out of the plane of Figure 14) in the deeper part of the basin during high lake level. This sediment may be derived from either the hanging-wall margin, as in the case of the South Rukuru study area (South Ruhuhu River), or some other axial source. As discussed above, the axial channel associated with these deposits may migrate toward the footwall block over time because of increasing tectonic subsidence rates toward the footwall block.

Following a drop in lake level, the depositional systems and pathways are once again reconfigured (Fig. 14D). In Figure 14D, the presence of a second canyon incised into the relay ramp has captured most of the sediment delivered to the relay ramp. Consequently, the relict mouth-of-canyon fan is blanketed by a mixture of fine-grained mud and locally derived gravity deposits. A mouth-of-canyon fan develops along the mouth of the adjacent canyon, thereby producing the shingled geometry observed in the South Rukuru seismic dataset (Fig. 12). The cause of the switch to an adjacent canyon may be tectonic activity on the relay ramp. Both downto-the-south and down-to-the-north northwest-trending faults occur on the relay ramp. Therefore minor movement along one of these faults may block sediment dispersal, shunting the sediment into a different canyon, producing a relatively random alternation among the different canyons. Preliminary structural analysis of the relay ramp, however, suggests that the relay ramp has experienced an overall north-to-south collapse. Therefore, through time, the canyons to the south would receive a higher proportion of sediment as the more northern canyons become isolated on the "relatively" uplifted part of the relay ramp.

Gawthorpe et al. (1994) have developed a general sequence stratigraphic model for extensional systems, based on the data from Greece and other modern and recent extensional settings. In this model, they propose that fan deltas developed along major basin-bounding faults show predominantly an aggradational geometry dominated by highstand systems tract deposits. Transgressive and lowstand systems tracts are not well developed in these fan deltas, particularly where sediment supply is high. They suggest that the high rate of subsidence along the extensional fault cancels out any eustatic drop in sea/lake level, effectively creating a continuous albeit fluctuating relative rise in base level.

The data from Lake Malawi suggest that continued aggradation of coarse-grained sediments along a border-fault margin through both highstand and lowstand conditions suggested by the model of Gawthorpe et al. (1994) may not be applicable when a synthetic border fault and more than one sub-lacustrine canyon are present along the margin. In the modern configuration of Lake Malawi, aggradation of coarse-grained sediment occurs in front of one active canyon, but upon a climatically driven fluctuation in lake level, coupled with tectonic activity on the relay ramp, deposition and sediment transport switch to an adjacent canyon after a rise and subsequent drop of lake level. During the subsequent depositional interval aggradation occurs at the base of the newly active canyon, but onlapping and draping of fine-grained sediments predominates over the older fan deposit. Thus lake-level fluctuation controls the ultimate thickness of these base-of-slope-fan deposits because, assuming sufficient subsidence and sediment supply, aggradation of the coarse-grained sediment occurs until a drop in lake level forces a switch of active deposition to another canyon. Therefore, the maximum thickness of the mouth-of-canyon fan is controlled by the duration of these climatically driven lake-level fluctuations. We have not attempted to determine the duration of these climatically driven fluctuations expressed in the alternating lobe position. However, lake-level fluctuations, which affect stacking patterns of coarse-grained deposits, on a time scale of roughly 80 to 100 ky have been estimated from short-term sedimentation rates applied to seismic data in other parts of Lake Malawi (Scholz and Finney 1994) and in Lake Tanganyika (Lezzar et al. 1996).

\section{SUMMARY AND CONCLUSIONS}

(1) Over $2900 \mathrm{~km}$ of single-channel seismic data, coupled with 20 deepwater vibracores, were taken from offshore of the South Rukuru River of Lake Malawi, Africa to develop a depositional model for coarse-grained 

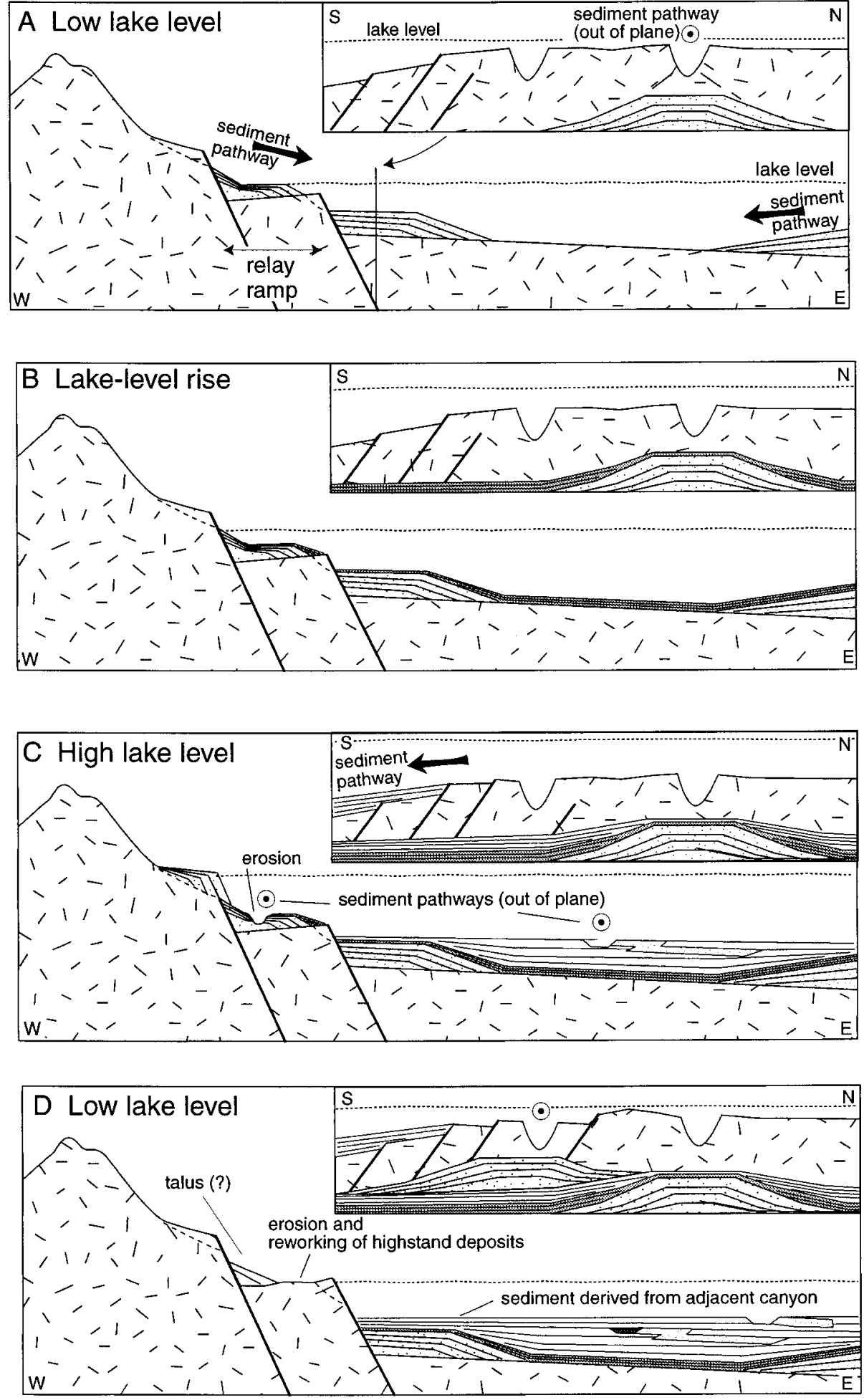

FIG. 14.-Summary of development of shingled mouth of canyon fans. A) Initial lowlake-level conditions. Sediment travels across relay ramp and is delivered to mouth-of-canyon fan from footwall block of major border fault. Only one (northern) canyon is active as shown in inset. B) Rapid rise in lake level.

Sedimentation on mouth-of-canyon fan is reduced as canyon and relay ramp are drowned by rising lake level. Region is draped by finegrained sedimentation. C) High-lake-level conditions. Sediment is ponded on actively prograding fan delta on footwall side of major border fault. Subaqueous sedimentation is directed down the relay ramp, parallel to shoreline as depicted in inset, and developing the basin-plain-fill facies that onlaps the relay ramp. The previous lowstand fan delta is also incised. Axial sedimentation in the deeper part of the basin also predominates. The inset also depicts the relay ramp collapsing, with faults progressively developing northward. D) Subsequent lowstand conditions. Erosion and reworking of previously deposited sediment dominates on relay ramp. The drop in lake level, coupled with continued collapse of relay ramp, shifts sediment dispersal to a different canyon, as shown in inset. Consequently, a mouth-ofcanyon fan does not develop along dip profile; instead sediment derived from adjacent canyon continues to drape and onlap underlying fan. sedimentation along a border-fault segment of an active extensional lacustrine basin.

(2) Five sand-dominated facies are identified from the single-channel seismic and core data: (1) mouth-of-canyon-fan facies; (2) canyon-fill facies; (3) channel-fill facies; (4) basin-plain-fill facies; and (5) progradational-fan-delta facies. These facies occur both in the modern geomorphic system as well as in the subsurface.
(3) Tectonic variables that control the distribution of the sand-dominated facies include fault orientation, the presence of a relay ramp, fault-driven footwall uplift and rotation, and temporal changes in subsidence. Fault orientation and deformation on the relay ramp controls the orientation of sub-lacustrine canyons as well as the offshore positioning of the mouth-ofcanyon fans. Fault-driven footwall uplift and rotation allows for deep incision of the sub-lacustrine canyons into the footwall, preventing any sig- 
nificant avulsion of the canyon. Temporal changes in subsidence influenced the stacking of the base-of-slope fans as well as the lateral position of the axial channel that is present basinward of the outermost fault system.

(4) Lake-level fluctuations control the position of progradational-fandelta facies and mouth-of-canyon-fan facies derived from the South Rukuru River as well as distal turbidite deposition from the Ruhuhu River, which is located on the opposite side of Lake Malawi. Lake-level fluctuations also control the maximum thickness of the mouth-of-canyon-fan deposits; as lake level rises and subsequently drops, active sedimentation switches to an alternate canyon, cutting off sedimentation to the aggrading fan. This temporal switching of the active canyon is also controlled by the tectonic collapse and internal faulting of the relay ramp.

\section{ACKNOWLEDGMENTS}

The authors would like to thank the governments of Malawi and Tanzania for granting permission to conduct the field work, and in particular we thank Chancellor College of the University of Malawi, the Malawi Geological Survey, and the Tanzania Petroleum Development Corporation for their assistance. The field work would not have been possible without the assistance of the Malawi Department of Fisheries, Monkey Bay; the Malawi Railways Monkey Bay shipyard, and ICEADA, the Icelandic AID organization. We thank the captain and crew of the R/V Ndunduma for their extensive help during the field program, and James McGill for his leadership during all phases of the field work. James Halfman assisted in data collection and shared unpublished limnologic data with us. We would also like to thank Peter Cattaneo, Jesse McNinch, and Jannard Lapuken for their assistance in data collection and in various phases of preparation and data analysis. Seismic data were interpreted using software obtained on a grant from Landmark Graphics Corporation.

The Lake Malawi Sublacustrine Fan Study was supported by the following corporations: Amoco, Anadarko, ARCO, Chevron, Exxon, Texaco, Occidental, and Unocal. We also thank Amoco for measuring sediment core physical properties at their Tulsa technology center. We thank M. Roberts, M. Lewis and associate editor B. Ricketts for their helpful reviews.

\section{REFERENCES}

Abrahao, D., AND Warme, J.E., 1990, Lacustrine and associated deposits in a rifted continental margin - Lower Cretaceous Lagoa Feia Formation, Campos Basin, Offshore Brazil, in Katz, B.J., ed., Lacustrine Basin Exploration-Case Studies and Modern Analogs: American Association of Petroleum Geologists, Memoir 50, p. 287-306.

Barnett, J.A.M., Mortimer, J., Rippon, J.H., Walsh, J.J., and Watterson, J., 1987, Displacement geometry in the volume containing a single normal fault: American Association of Petroleum Geologists, Bulletin, v. 71, p. 925-937.

Bertani, R.T., and Carozzi, A.V., 1984, Lagoa Feia Formation (Lower Cretaceous), Campos Basin, offshore Brazil: Rift valley stage lacustrine carbonate reservoirs-I: Journal of Petroleum Geology, v. 8, p. 37-58.

Blair, T.C., AND Bilodeau, W.L., 1988, Development of tectonic cyclothems in rift, pull-apart and foreland basins: sedimentary response to episodic tectonism: Geology, v. 16, p. 517520.

BRACKEN, B.R., 1994, Synrift lacustrine beach and deltaic sandstone reservoirs-pre-salt (Lower Cretaceous) of Cabinda, Angola, west Africa, in Lomando, A.J., Shreiber, B.C., and Harris, P.M., eds., Lacustrine Reservoirs and Depositional Systems: SEPM, Core Workshop 19, p. 173-200.

Butzer, K.W., IsaAc, G.L., Richardson, J.L., and Washbourn-Kamau, C., 1972, Radiocarbon dating of East African lake levels: Science, v. 175, p. 1069-1076.

Crossley, R., 1984, Controls of sedimentation in the Malawi Rift Valley, central Africa: Sedimentary Geology, v. 40, p. 33-50.

Dart, C.J., Collier, R.E.L., Gawthorpe, R.L., Keller, J.V.A., and Nichols, G., 1994, Sequence stratigraphy of (?)Pliocene-Quaternary synrift, Gilbert-type fan deltas, northern Peloponnesos, Greece: Marine and Petroleum Geology, v. 11, p. 545-560.

Ebinger, C.J., 1989a, Tectonic development of the western branch of the East African Rift System: Geological Society of America, Bulletin, v. 101, p. 885-903.

EBINGER, C.J., 1989b, Geometric and kinematic development of border faults and accommodation zones, Kivu-Ruzizi Rift, Africa: Tectonics, v. 8, p. 117-133.

Ebinger, C.J., Rosendahl, B.R., And Reynolds, D.J., 1987, Tectonic evolution of the Malawi rift, Africa: Tectonophysics, v. 141, p. 215-235.

GaWthoRPe, R.L., AND Colella, A., 1990, Tectonic control on coarse-grained delta depositional systems in basins, in Colella, A., and Prior, D., eds., Coarse Grained Deltas: International Association of Sedimentologists, Special Publication 10, p. 113-127.

Gawthorpe, R.L., Fraser, A.J., and Collier, R.E.L., 1994, Sequence stratigraphy in active extensional basins: Implications for the interpretation of ancient basin-fills: Marine and Petroleum Geology, v. 11, p. 642-658.

Haberyan, K.A., AND HECKY, R.E., 1987, The late Pleistocene and Holocene stratigraphy and paleolimnology of Lakes Kivu and Tanganyika: Palaeogeography, Palaeoclimatology, $\mathrm{Pa}$ laeoecology, v. 61, p. 169-197.
HaLfman, J.D., 1993, Water column characteristics from modern CTD data, Lake Malawi, East Africa: Journal of Great Lakes Research, v. 19, p. 512-520.

Harris, N.B., Sorriaux, P., and Toomey, D.F., 1994, Geology of the Lower Cretaceous Viodo Carbonate, Congo Basin: A lacustrine carbonate in the South Atlantic rift, in Lomando, A.J., Shreiber, B.C., and Harris, P.M., eds., Lacustrine Reservoirs and Depositional Systems: SEPM, Core Workshop 19, p. 143-172

Johnson, T.C., Wells, J.T., And Scholz, C.A., 1995, Deltaic sedimentation in a modern rift lake: Geological Society of America, Bulletin, v. 107, p. 812-829.

King, G.C., Stein, R.S., And Rundle, J.B., 1988, The growth of geophysical structures by repeated earthquakes: 1 . Conceptual framework: Journal of Geophysical Research, v. 93, p. $13,307-13,318$.

KusZNIR, N.J., AND Egan, S.S., 1990, Simple-shear and pure-shear models of extensional sedimentary basin formation: Application to the Jeanne D'Arc basin, Grand Banks of Newfoundland, in Tankard, A.J., and Balkwill, H.R., eds., Extensional Tectonics of the Northern Atlantic Margins: American Association of Petroleum Geologists, Memoir 46, p. 305-322.

Lezzar, K.E., Tiercelin, J.J., De Batist, M., Cohen, A.S., Bandora, T., Van Rensbergen, P., Le Turdu, C.W.M., And KlerX, J., 1996, New seismic stratigraphy and Late Tertiary history of the North Tanganyika Basin, East African Rift system, deduced from multichannel and high-resolution reflection seismic data and piston core evidence: Basin Research, v. 8, p. $1-28$.

Livingstone, D.A., 1965, Sedimentation and the history of water level change in Lake Tanganyika: Limnology and Oceanography, v. 10, p. 607-610.

Ma Li, Ge Taisheng, Zhao Xueping, Zie Taijun, Ge Rong, and Dang Zhenrong, 1982, Oil basins and subtle traps in the eastern part of China, in Halbouty, M.T., ed., The Deliberate Search for the Subtle Trap: American Association of Petroleum Geologists, Memoir 32, p. 287-315.

MaCK, G.H., AND SEAGER, W.R., 1990, Tectonic control on facies distribution of the Camp Rice and Palomas Formations (Pliocene and Pleistocene) in the southern Rio Grande rift: Geological Society of America, Bulletin, v. 102, p. 45-53.

Magnavita, L.P., and da Silva, H.T.F., 1995, Rift border system: The interplay between tectonics and sedimentation in the Reconcavo Basin, Northeastern Brazil: American Association of Petroleum Geologists, Bulletin, v. 79, p. 1590-1607.

Malawi Department of Surveys, 1983, National Atlas of Malawi: Blantyre, Malawi.

Martin, M.R., 1997, The sequence stratigraphy of a rift lake flexural margin delta: Dwangwa Delta, Lake Malawi, East Africa [unpublished M.S. thesis]: University of Houston, Houston, Texas, $137 \mathrm{p}$.

McHargue, T., 1990, Stratigraphic development of proto-South Atlantic rifting in Cabinda, Angola-A petroliferous lake basin, in Katz, B.J., ed., Lacustrine Basin Exploration-Case Studies and Modern Analogs: American Association of Petroleum Geologists, Memoir 50, p. 307-326.

Morley, C.K., Nelson, R.A., Patton, T.L., and Munn, S.G., 1990, Transfer zones in the East African Rift System and their relevance to hydrocarbon exploration in rifts: American Association of Petroleum Geologists, Bulletin, v. 74, p. 1234-1253.

Nelson, R.A., Patton, T.L., and Morley, C.K., 1992, Rift segment interaction and its relation to hydrocarbon exploration in continental rift systems: American Association of Petroleum Geologists, Bulletin, v. 76, p. 1153-1169.

Owen, R.B., Crossley, R., Johnson, T.C., Tweddle, D., Kornfield, I., Davison, S., and Eccles, D.H., 1990, Major low levels of Lake Malawi and their implications for speciation rates in cichlid fishes: Royal Society [London], Proceedings, Series B, Biological Sciences, v. 240, p. $519-553$.

Posamentier, H.W., AND Vail, P.R., 1988, Eustatic controls on clastic deposition II-sequence and system tract models, in Wilgus, C.K., Hastings, B.S., Kendall, C.G.St.C., Posamentier, H.W., Ross, C.A., and Van Wagoner, J.C., eds., Sea-Level Changes: An Integrated Approach: SEPM, Special Publication 42, p. 125-154.

RosendaHL, B.R., 1987, Architecture of continental rifts with special reference to east Africa: Annual Review of Earth and Planetary Sciences, v. 15, p. 445-503.

Rosendahl, B.R., Reynolds, D.J., Lorber, P.M., Burgess, C.F., McGill, J., Scott, D., LamBiase, J.J., and Derksen, S.J., 1986, Structural expressions of rifting: Lessons from Lake Tanganyika, in Frostick, L.E., Renaut, R.W., Reid, I., and Tiercelin, J.J., eds., Sedimentation in the African Rifts: Geological Society of London, Special Publication 25, p. 29-44.

ScHolz, C.A., 1995a, Seismic stratigraphy of an accommodation-zone margin rift-lake delta, Lake Malawi, Africa, in Lambiase, J.J., ed., Hydrocarbon Habitat in Rift Basins: Geological Society of London, Special Publication 80, p. 183-196.

Scholz, C.A., 1995b, Deltas of the Lake Malawi Rift, East Africa: Seismic expression and exploration implications: American Association of Petroleum Geologists, Bulletin, v. 79, p. 1679-1697.

Scholz, C.A., AND FinNey, B.P., 1994, Late Quaternary sequence stratigraphy of Lake Malawi (Nyasa), Africa: Sedimentology, v. 41, p. 163-179.

Scholz, C.A., AND Rosendahl, B.R., 1988, Low lake stands in Lake Malawi and Tanganyika, East Africa, delineated with multifold seismic data: Science, v. 240, p. 1645-1648.

Scholz, C.A., Johnson, T.C., And McGill, J.W., 1993, Deltaic Sedimentation in a rift valley lake: New seismic reflection data from Lake Malawi (Nyasa), East Africa: Geology, v. 21, p. 395-398.

Shanmugam, G., and Moiola, R.J., 1991, Types of submarine fan lobes: Models and implications: American Association of Petroleum Geologists, Bulletin, v. 75, p. 156-179.

Shanmugam, G., Moiola, R.J., and Damuth, J.E., 1985, Eustatic control of submarine fan development, in Bouma, A.H., and Barnes, N.E., eds., Submarine Fans and Related Turbidite Systems: New York, Springer-Verlag, p. 23-28.

Soreghan, M.J., AND CoHEn, A.S., 1996, Textural and compositional variability across littoral segments of Lake Tanganyika: The effect of asymmetric basin structure on sedimentation in large rift lakes: American Association of Petroleum Geologists, Bulletin, v. 80, p. 382 409. 
SPECHT, T.D., AND RosendAHL, B.R., 1989, Architecture of the Lake Malawi Rift, Africa: Journal of African Earth Sciences, v. 8, p. 355-382.

Tiercelin, J.J., Soreghan, M.J., Cohen, A.S., Lezzar, K.E., and Bouroullec, J.L., 1992, Sedimentation in large rift lakes: Example from the Middle Pleistocene-Modern deposits of the Tanganyika trough, East African Rift System: Centres Recherche Exploration et Production, Elf Aquitaine, Bulletin, v. 16, p. 83-111.

Walsh, J.J., and WatTeRson, J., 1989, Displacement gradients on fault surfaces: Journal of Structural Geology, v. 11, p. 307-316.

WeImer, P., AND LinK, M.H., 1991, Seismic facies and sedimentary processes of submarine fans and turbidite systems: New York, Springer-Verlag, Frontiers in Sedimentary Geology, p. $1-447$.
Weissel, J.K., AND Karner, G.D., 1989, Flexural uplift of rift flanks due to mechanical unloading of the lithosphere during extension: Journal of Geophysical Research, v. 94, p. $13,919-13,950$.

Wells, J. T., Scholz, C.A., and Soreghan, M.J., 1999, Processes of sedimentation on a lacustrine border fault margin: Interpretation of cores from Lake Malawi, East Africa: Journal of Sedimentary Research, v. 69, p. 816-831.

ZHA, QuANHENG, 1984, Jizhong depression, China-its geologic framework, evolutionary history, and distribution of hydrocarbons: American Association of Petroleum Geologists, Bulletin, v. 68, p. 983-992.

Received 12 January 1998; accepted 4 October 1998. 